Article

\title{
Effect of Gibberellic Acid on Growth, Yield, and Quality of Leaf Lettuce and Rocket Grown in a Floating System
}

\author{
Alessandro Miceli * ${ }^{\mathbb{D}}$, Alessandra Moncada, Leo Sabatino $\mathbb{D}$ and Filippo Vetrano \\ Dipartimento Scienze Agrarie, Alimentari e Forestali, Università di Palermo, Viale delle Scienze 4, \\ 90128 Palermo, Italy \\ * Correspondence: alessandro.miceli@unipa.it; Tel.: +39-0912-3862-219
}

Received: 9 June 2019; Accepted: 12 July 2019; Published: 16 July 2019

\begin{abstract}
Gibberellins (GAs) are growth hormones strongly involved in a wide variety of physiological activities. Currently, gibberellins are commercially used to enhance phenotypic characteristics, earliness, and productivity of many vegetable and ornamental crops. In this work, the efficacy of supplementation of low levels of gibberellic acid $\left(0,10^{-8}, 10^{-6}\right.$, and $\left.10^{-4} \mathrm{M} \mathrm{GA}_{3}\right)$ through the mineral nutrient solution of a floating system on yield and quality of leaf lettuce and rocket plants was tested. The marketability of plants was lost when $10^{-4} \mathrm{M} \mathrm{GA}_{3}$ was added to the mineral nutrient solution. This study demonstrated that the addition of $10^{-4} \mathrm{M} \mathrm{GA}_{3}$ exceeded the acceptable threshold for use in hydroponics production systems. Below the concentration of $10^{-4} \mathrm{M}$, the presence of $\mathrm{GA}_{3}$ in the mineral nutrient solutions (MNS), especially at $10^{-6} \mathrm{M} \mathrm{GA}_{3}$, stimulated plant growth and enhanced the yield. Various morphological and physiological traits were enhanced by $\mathrm{GA}_{3}$ treatments (biomass accumulation, leaf expansion, stomatal conductance, water use efficiency (WUE), Nitrogen use efficiency (NUE), etc.), with superimposable trends in both lettuce and rocket. The addition of $10^{-6} \mathrm{M} \mathrm{GA}_{3}$ to the nutrient solution of a hydroponic floating system can promote growth and quality of lettuce and rocket plants.
\end{abstract}

Keywords: gibberellic acid; $\mathrm{GA}_{3}$; leafy vegetables; lettuce; rocket; hydroponics; floating system

\section{Introduction}

Recently, consumers' consciousness of the importance of eating healthy foods [1-5] has raised notably. This is strictly related to the awareness of the consumers that an increase of vegetable intake might reduce the risk of cancers as well as many other degenerative diseases [6,7]. As a consequence of this phenomenon, the demand for vegetables increased over the past 25 years with the result that the world's value of trade in vegetables overcame that of cereals [8]. To fulfill this growing request for vegetables, it became necessary to enhance the productivity of vegetable crops with environmentally friendly, cost-effective, and easy to use techniques. These goals might be reached in many ways, such as genetic improvement, innovative cultivation systems, grafting, growth promoting microorganism, and plant growth regulators [9-13].

Since their discovery, natural and synthetic plant growth regulators have been increasingly used in agriculture and in horticulture to modify crop plants by controlling plant developmental processes (germination, vegetative growth, reproductive development, maturity, senescence, and postharvest preservation) [14]. Among these, gibberellins (GAs) are essential endogenous hormones found in plants and fungi controlling plant development by regulating several physiological mechanisms [15]. GAs can stimulate stem and root elongation, leaf expansion, flowering, fruit senescence, seed germination, or dormancy [16]. They induce transcription of genes involved in cell elongation and cell division occurring 
during growth [17]; moreover, they can also stimulate the expression of hydrolytic enzymes involved in the conversion of starch to sugar [14]. By controlling starch accumulation and use, gibberellin can influence overall plant growth. Thus, the GA signal in plant tissue can be converted into alterations in gene expression, plant physiology and morphology [17]. When the gibberellin-based products became commercially available, the astonishing results obtained from their application to many crops raised great expectations of consistently increasing plant productivity [18]. Exogenous applications of gibberellins were shown to actively influence various physiological activities, such as vegetative growth, flowering and flower morphology, earliness, fruit set, ion transport and osmoregulation, leaf area expansion, internode elongation and can also increase biomass production, fruit weight and dry matter [19-28]. These effects can vary greatly depending on hormone requirement, relative concentrations, and plant responses at different growth stages [29]. Many studies have focused the attention on the use of this phytohormone for improving the productivity and quality of several crop plants [30-37]. GAs have been commercially applied to control the vegetative growth of many horticultural crops. They might increase seed yield in firm-headed lettuce, enhance growth and sugar accumulation in sugar cane, accelerate peduncle elongation and bud development in artichokes and strawberry, etc. Recently, the application of exogenous gibberellic acid $\left(\mathrm{GA}_{3}\right)$ has gained a renewed interest with the aim to promote plant growth, improve yield and increase tolerance to abiotic stresses (e.g., drought, heat, salinity) [22-24,30,32,38,39]. Foliar sprays of low concentration of $\mathrm{GA}_{3}$ has been tested with promising results on performance, quality, and salt tolerance of various fruit and seed vegetables both in soil and in hydroponic cultivation systems [30-33,36,38,40,41]. So far, the information available on the effects of gibberellic acid application on leafy vegetables grown in hydroponic systems are quite scarce. The relations among $\mathrm{GA}_{3}$ supply through foliar spray or through the nutrient solution and yield, quality, and post-harvest life of these vegetables still need further investigations. The quality of leafy vegetables is strictly related to leaf appearance and nutritional value (vitamin C, nitrates, antioxidants, etc.). Gibberellins may play a key role in many metabolic pathways affecting these characteristics, such as chlorophyll production and degradation, translocation of assimilates, nitrogen metabolism, and nitrogen redistribution. As stated above, these effects can vary greatly among different species, growth stages, application dose and methods, and cultivation techniques. Therefore, the present study was aimed at characterizing the effect of adding gibberellic acid $\left(\mathrm{GA}_{3}\right)$ to the mineral nutrient solution on growth, yield, and quality of leaf lettuce and rocket grown in a floating system.

\section{Materials and Methods}

\subsection{Leafy Vegetable Cultivation}

This study was carried out in greenhouse conditions at the Department of Agricultural, Food and Forest Sciences (SAAF-University of Palermo, Italy) (38 $6^{\prime} 28^{\prime \prime} \mathrm{N}, 13^{\circ} 21^{\prime} 3^{\prime \prime} \mathrm{E}$; altitude $\left.49 \mathrm{~m}\right)$. Plants of leaf lettuce (Lactuca sativa L. var. Crispa) and rocket (Eruca sativa L.) were cultivated in a hydroponic floating system using nutrient solutions with four concentrations of $\mathrm{GA}_{3}$ (Gibrelex, Biolchim, Bologna, Italy): $0,10^{-8}, 10^{-6}$, and $10^{-4} \mathrm{M} \mathrm{GA}_{3}$. The mineral nutrient solutions (MNS), prepared using tap water (electrical conductivity (EC) $480 \mu \mathrm{S} \mathrm{cm}{ }^{-1}$; pH 7.6), contained $4.5 \mathrm{mmol} \mathrm{L}^{-1}$ of $\mathrm{Ca}^{2+}, 2 \mathrm{mmol} \mathrm{L}^{-1}$ of $\mathrm{H}_{2} \mathrm{PO}_{4}^{-}, 1.25 \mathrm{mmol} \mathrm{L}^{-1}$ of $\mathrm{NH}_{4}^{-}, 1 \mathrm{mmol} \mathrm{L}{ }^{-1}$ of $\mathrm{Mg}^{2+}, 19 \mathrm{mmol} \mathrm{L}^{-1}$ of $\mathrm{NO}_{3}^{-}, 11 \mathrm{mmol} \mathrm{L}^{-1}$ of $\mathrm{K}^{+}$, $1.1 \mathrm{mmol} \mathrm{L}^{-1}$ of $\mathrm{SO}_{4}{ }^{2-}, 40 \mu \mathrm{mol} \mathrm{L}-1$ of $\mathrm{Fe}^{3+}, 5 \mu \mathrm{mol} \mathrm{L}^{-1}$ of $\mathrm{Mn}^{2+}, 4 \mu \mathrm{mol} \mathrm{L}^{-1}$ of $\mathrm{Zn}^{2+}, 30 \mu \mathrm{mol} \mathrm{L}^{-1}$ of $\mathrm{BO}_{3}{ }^{3}, 0.75 \mu \mathrm{mol} \mathrm{L}-1$ of $\mathrm{Cu}^{2+}$, and $0.50 \mu \mathrm{mol} \mathrm{L}{ }^{-1}$ of Mo [42], and differed only in $\mathrm{GA}_{3}$ concentration. The mineral nutrient solution had an EC of $2.25 \mathrm{mS} \mathrm{cm}^{-1}$ and a $\mathrm{pH}$ of 5.8. Each MNS was poured into 4 different tanks $(100 \mathrm{~cm}$ long $\times 50 \mathrm{~cm}$ wide $\times 15 \mathrm{~cm}$ deep, containing $75 \mathrm{~L}$ ). Seedlings with 3 to 4 true leaves of leaf lettuce (cv. 'Lattuga da Taglio a Foglia Liscia', Sementi Dotto-SDD SPA, Udine, Italy) and rocket (cv. 'Coltivata da orto', Sementi Dotto-SDD SPA, Udine, Italy), grown in polystyrene trays (160 holes), were transplanted (28 February) in drilled polystyrene panels $\left(400\right.$ plants $\mathrm{m}^{-2}$ ) that were then placed to float in the tanks (Figure 1). 

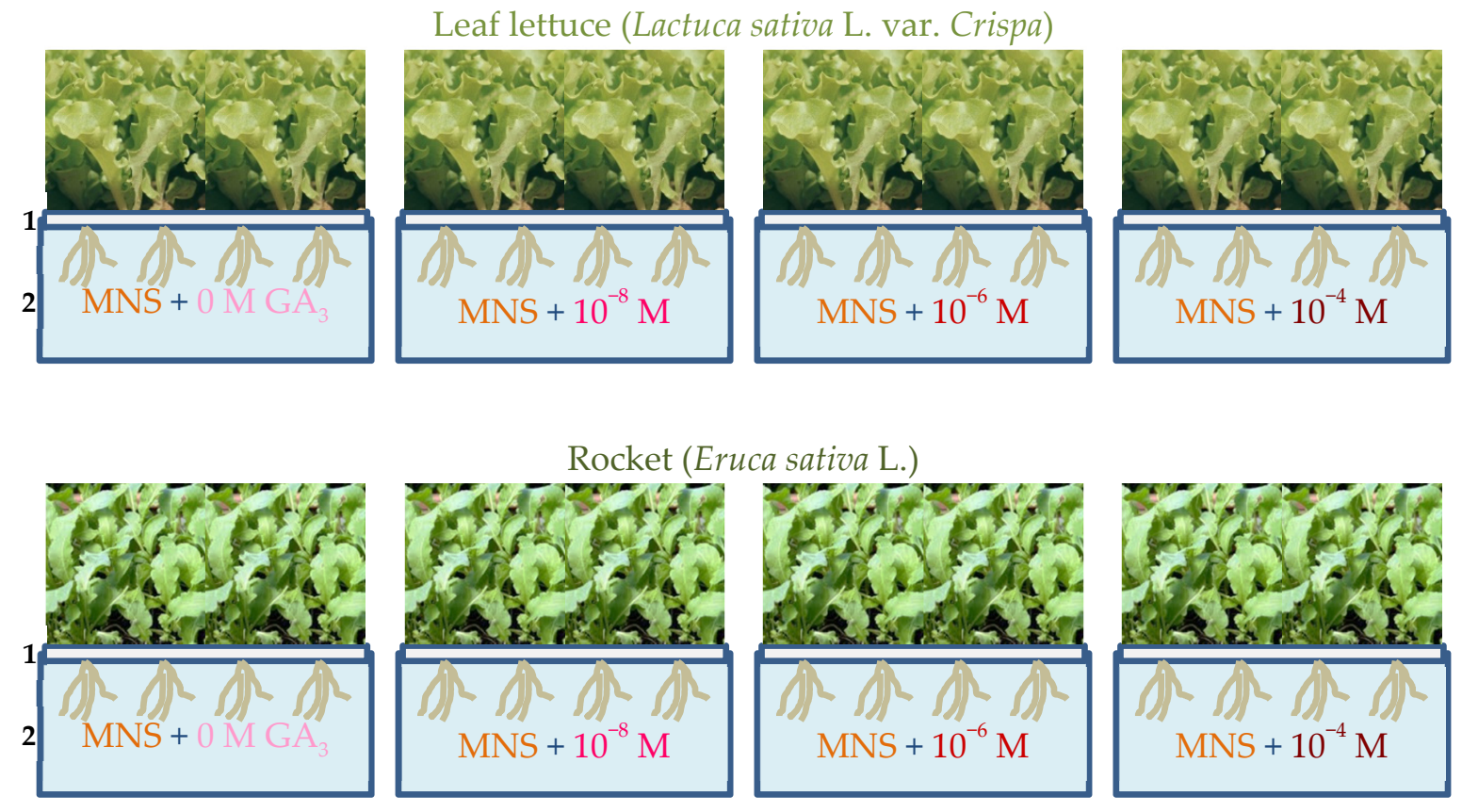

Figure 1. Graphical representation of the hydroponic floating system consisting of drilled polystyrene panels floating on mineral nutrient solutions (MNS) with different level of gibberellic acid $\left(\mathrm{GA}_{3}\right)$ ( ${ }^{1}$ Drilled polystyrene panels ( 400 plants $\mathrm{m}^{-2}$ ) floating on MNS; ${ }^{2}$ Tanks containing $75 \mathrm{~L}$ of MNS added with increasing concentrations of $\mathrm{GA}_{3}$ ).

Each treatment was composed of four replicated tanks for each $\mathrm{GA}_{3}$ concentration (200 plants for each tank; 16 tanks for each species). The MNSs were not aerated during crop cultivation because leafy vegetables have a fast growth and do not require high oxygen concentration in the hydroponic solution [43]. The MNS was regularly checked to assess water consumption and EC and $\mathrm{pH}$ modifications. The tanks were refilled with new MNS, with the same $\mathrm{GA}_{3}$ concentration, when the volume dropped by $20 \%$. The consumption of MNS was measured for each experimental treatment. The MNS in the tanks was completely covered by the polystyrene panels. Hence, the amount of water loss through evaporation was negligible and was not considered. This allowed calculating the water use efficiency (WUE) as WUE ( $\mathrm{g}$ DW L ${ }^{-1} \mathrm{H}_{2} \mathrm{O}$ ) = plant dry weight $(\mathrm{g}) / \mathrm{H}_{2} \mathrm{O}(\mathrm{L})$. At harvest, the MNS in the tanks was analyzed to calculate the residual amount of $\mathrm{N}_{-} \mathrm{NH}_{4}{ }^{+}$and $\mathrm{N}^{-\mathrm{NO}_{3}}{ }^{-}$(determined reflectometrically by a Merck RQflex10 reflectometer according to the company protocols (Merck, Darmstadt, Germany)). This allowed the estimation of the total $\mathrm{N}$ uptake during the crop cycle and to calculate Nitrogen use efficiency (NUE) [44] as NUE $\left(\mathrm{g} \mathrm{DW} \mathrm{g}^{-1} \mathrm{~N}\right)=$ plant total dry weight (g)/plant $\mathrm{N}$ uptake (g).

Stomatal conductance was measured ( $15 \mathrm{~d}$ after transplant) with a diffusion porometer (AP4, Delta-T Devices Ltd., Cambridge, England) on two recently expanded, unshaded leaves of 20 plants for each replicate.

All the plants were harvested 22 days after transplant, and marketable yield was calculated after eliminating decayed or yellowed older leaves. Then, 20 plants were randomly selected for each replicate and destructively sampled. Plant height, root length, leaf number, main leaf width (leaf lettuce), petiole length (rocket), and leaf area were determined. Leaf area was calculated for each plant by digital image analysis. Leaves were sampled, immediately weighed, then scanned with a resolution of 350 dpi (Epson Perfection 4180 Photo, Seiko Epson Corp, Suwa, Japan); the images were analyzed with the ImageJ 1.52a software (National Institutes Health, Bethesda, MD, USA). Scanned leaves were dried at $85{ }^{\circ} \mathrm{C}$ to a constant weight and re-weighed to calculate the specific leaf area (SLA cm $\mathrm{g}^{-1}$ ) as leaf area/leaf dry weight. Afterward, another 20 plants randomly selected for each replicate were 
separated into epigeal (stems and leaves) and hypogeal (roots) fractions, weighed and then dried to constant weight at $85^{\circ} \mathrm{C}$ for fresh and dry biomass determination.

A third sample of 20 plants for each replicate was used for leaf color measure and chemical determinations. Leaf color components $\left(\mathrm{L}^{*}, \mathrm{a}^{*}\right.$, and $\left.\mathrm{b}^{*}\right)$ were recorded with a colorimeter (CR-400, Minolta Corporation, Ltd., Osaka, Japan) at two areas of photosynthetic tissue on the upper part of twenty leaves, randomly selected for each leafy vegetable and each treatment. Hue angle $\left(\mathrm{h}^{\circ}\right)$ and Chroma $\left(C^{*}\right)$ were calculated as $h^{\circ}=180^{\circ}+\arctan \left(b^{*} / a^{*}\right)[45]$ and $C^{*}=\left(a^{* 2}+b^{* 2}\right)^{1 / 2}$. Twenty grams of leaves from each sample were then homogenized with $\mathrm{H}_{2} \mathrm{O}(1: 2 w / v)$, and the homogenates were centrifuged at $3500 \mathrm{rpm}$ for $10 \mathrm{~min}$. The extracts were used to determine soluble solid content (SSC), ascorbic acid and nitrate content, and titratable acidity (TA). SSC $\left({ }^{\circ}\right.$ Brix) determination was performed with a digital refractometer (MTD-045nD, Three-In-One Enterprises Co. Ltd., New Taipei City, Taiwan). Ascorbic acid and nitrate content (respectively, $\mathrm{mg} 100 \mathrm{~g} \mathrm{~g}^{-1}$ and $\mathrm{mg} \mathrm{kg}^{-1}$ of fresh weight) were determined reflectometrically by a Merck RQflex10 reflectometer according to the company protocols (Merck, Darmstadt, Germany). TA (expressed as mg of citric acid per $100 \mathrm{~g}$ of fresh weight) was determined by titrating $10 \mathrm{~mL}$ of extract with $0.1 \mathrm{M} \mathrm{NaOH}$ up to $\mathrm{pH}$ 8.1.

\subsection{Statistics and Principal Component Analysis}

The experimental layout consisted of four replicates for each $\mathrm{GA}_{3}$ level and each leafy vegetable randomly assigned in four blocks. To determine the effect of the $\mathrm{GA}_{3}$ level on each leafy vegetable, a one-way ANOVA was carried out. Differences between means were determined by Tukey's multiple-range test at the $5 \%$ level.

Principal components analysis (PCA) was performed to study the correlation among the different $\mathrm{GA}_{3}$ levels, and the agronomic and quality characteristics of leaf lettuce and rocket. The input matrix for the analysis comprised plant height, root length, whole plant fresh weight (FW), epigeal part (E) FW, roots (R) FW, E/R FW, whole plant dry weight (DW), epigeal part DW, roots DW, E/R DW, epigeal DW, root DW, yield, WUE, NUE, leaf no., plant area, leaf area, SLA, stomatal conductance, $L^{*}, a^{*}, b^{*}$, chroma, hue, SSC, TA, ascorbic acid and $\mathrm{N}^{-\mathrm{NO}_{3}}{ }^{-}$. The optimum number of principal components (PCs) was assessed by retaining the factors with eigenvalues higher than 1.0. Furthermore, the plot of the PCs allowed the investigation of the correlations between the variables of the input data set. With this regard, the initial variables were projected into the subspace defined by the first and second PCs, and correlated variables were determined. Principal component analysis was performed with SPSS version 13.0 (SPSS Inc., Chicago, IL, USA).

\section{Results}

During plant growth, the average temperature outside the greenhouse ranged between $18.0 \pm 0.3^{\circ} \mathrm{C}$ (day) and $10.4 \pm 0.4{ }^{\circ} \mathrm{C}$ (night) and the net solar radiation at noon was on average $467 \mathrm{~W} \cdot \mathrm{m}^{-2}$. The day length during the cultivation period (from sunrise to sunset) ranged between 11 and 12 hours. Inside the greenhouse, the mean air and MNS temperatures were $20.5 \pm 0.6^{\circ} \mathrm{C}$ and $17.3 \pm 0.3^{\circ} \mathrm{C}$, respectively. Air temperature ranged between $32.0 \pm 0.9^{\circ} \mathrm{C}$ (day) and $13.4 \pm 0.4{ }^{\circ} \mathrm{C}$ (night). During the experiment, the highest light intensity inside the greenhouse was 38,218 lux on average, ranging from 60,802 to 11,259 lux as a function of cloudiness.

The characteristics of the nutrient solutions in the tanks changed during plant growth, due to water absorption, as well as to MNS refills. During plant cultivation, the EC and $\mathrm{pH}$ of MNS had no significant differences due to $\mathrm{GA}_{3}$ treatments but showed a different trend for lettuce and rocket. The EC of MNS slightly decreased only for lettuce plants and, at harvest, reached $2.00 \mathrm{mS} \mathrm{cm}^{-1}$ on average, while the MNS of rocket plants did not vary their EC. The $\mathrm{pH}$ increased up to 6.50 and 6.76 , for lettuce and rocket, respectively.

During the first days after transplant, the plants of leaf lettuce and rocket grown in the MNS added with $\mathrm{GA}_{3}$ showed a visibly greater growth rate than those grown without exogenous gibberellic acid. After the first (lettuce) or the second week (rocket) from transplant, the plants grown with the highest 
$\mathrm{GA}_{3}$ concentration in the MNS $\left(10^{-4} \mathrm{M}\right)$ started to show leaf morphology modifications (narrow and elongated leaves) and lengthened internodes so that 10 to 14 days after transplant, the plants lost their marketability (Figure 2). Hence, plants grown with $10^{-4} \mathrm{M} \mathrm{GA}_{3}$ were not further examined. Lettuce and rocket plants were harvested at the same time 22 days after transplant.
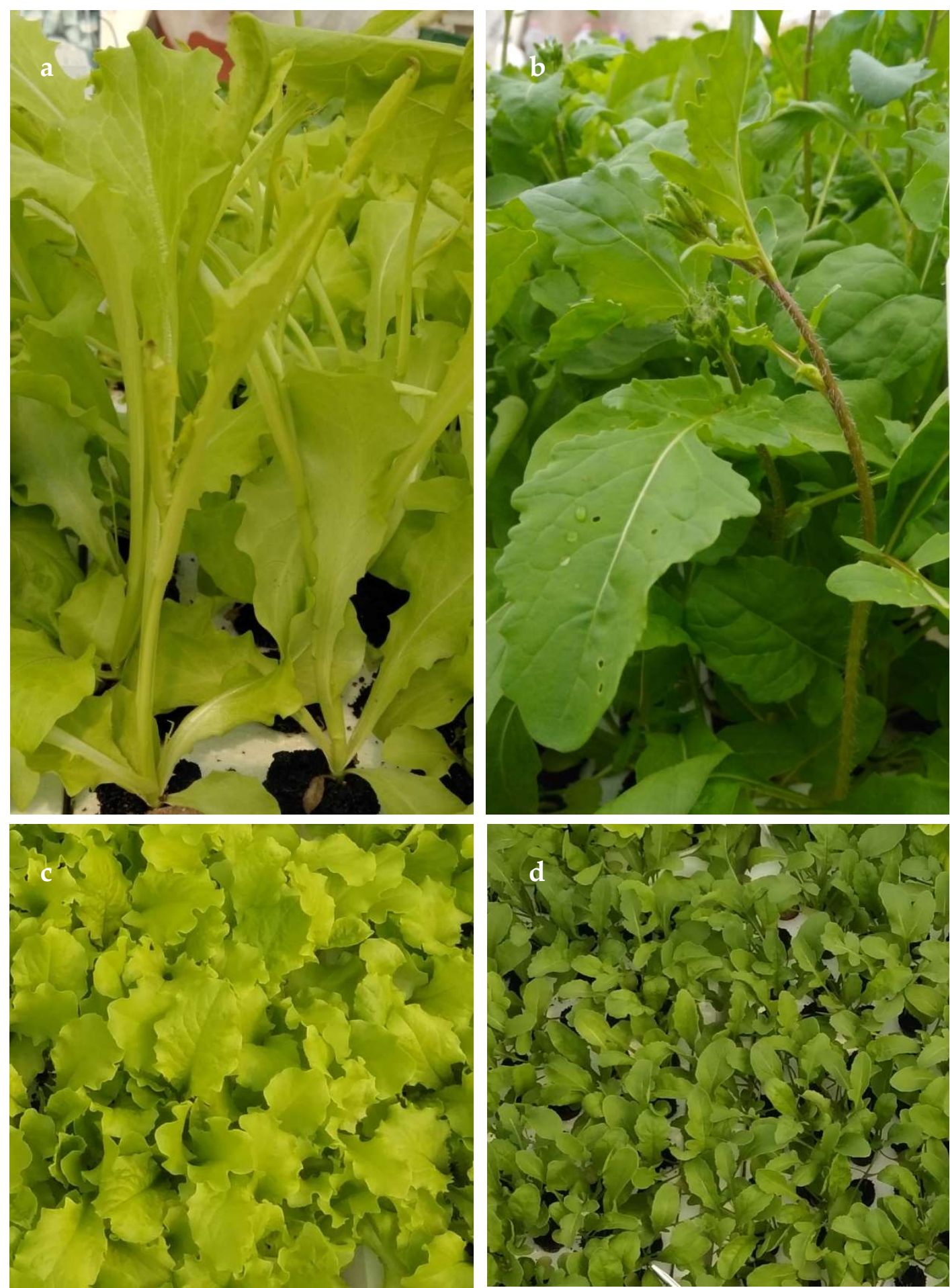

Figure 2. Plants of leaf lettuce $(\mathbf{a}, \mathbf{c})$ and rocket $(\mathbf{b}, \mathbf{d})$ after two weeks of cultivation on a mineral nutrient solution with $10^{-4} \mathrm{M} \mathrm{GA}_{3}$ and without $\mathrm{GA}_{3}$, respectively. 


\subsection{Morpho-Physiological Parameters and Yield of Leaf Lettuce}

At harvest, the height of leaf lettuce plants showed to be significantly influenced by the presence of $10^{-6} \mathrm{M} \mathrm{GA}_{3}$ in the MNS. At this concentration, plants were $6.8 \mathrm{~cm}$ higher than control plants $(25.0 \mathrm{~cm}$ ) but had no difference in root length (Table 1). The total fresh biomass of control plants was $13.4 \mathrm{~g} \mathrm{plant}^{-1}$, whereas the fresh weight of the plants grown with $10^{-6} \mathrm{M} \mathrm{GA}_{3}$ in the MNS was $41.1 \%$ higher (Table 1; Figure 2). The higher plant fresh weight derived from the increase of the epigeal part (E) weight $(+44.5 \%)$, as the root weight $(\mathrm{R})$, showed no significant difference due to the treatments. Therefore, the $\mathrm{E} / \mathrm{R}$ ratio significantly increased from 8.3 in control plants up to 10.7 in the plants grown with $10^{-6} \mathrm{M} \mathrm{GA}_{3}$ (Table 1 ).

Table 1. Yield and morphological parameters of leaf lettuce plants grown in nutrient solutions containing different levels of gibberellic acid $\left(\mathrm{GA}_{3}\right)$.

\begin{tabular}{cccc}
\hline & \multicolumn{3}{c}{$\mathbf{G A}_{\mathbf{3}} \mathbf{( M )}$} \\
\cline { 2 - 4 } & $\mathbf{0}$ & $\mathbf{1 0}^{-8}$ & $\mathbf{1 0}^{-\mathbf{6}}$ \\
\hline Plant height $(\mathrm{cm})$ & $25.0 \mathrm{~b}^{1}$ & $25.2 \mathrm{~b}$ & $31.8 \mathrm{a}$ \\
Root length $(\mathrm{cm})$ & $31.1 \mathrm{a}$ & $30.7 \mathrm{a}$ & $32.0 \mathrm{a}$ \\
Plant fresh weight & & & \\
Whole plant $(\mathrm{g})$ & $13.4 \mathrm{~b}$ & $14.7 \mathrm{~b}$ & $18.9 \mathrm{a}$ \\
Epigeal part $(\mathrm{g})$ & $12.0 \mathrm{~b}$ & $13.2 \mathrm{~b}$ & $17.3 \mathrm{a}$ \\
Roots $(\mathrm{g})$ & $1.4 \mathrm{a}$ & $1.5 \mathrm{a}$ & $1.6 \mathrm{a}$ \\
Epigeal/Roots Ratio & $8.3 \mathrm{~b}$ & $8.8 \mathrm{~b}$ & $10.7 \mathrm{a}$ \\
Plant dry weight & & & \\
Whole plant (g) & $0.47 \mathrm{~b}$ & $0.57 \mathrm{~b}$ & $0.75 \mathrm{a}$ \\
Epigeal part (g) & $0.39 \mathrm{~b}$ & $0.49 \mathrm{~b}$ & $0.66 \mathrm{a}$ \\
Roots (g) & $0.07 \mathrm{a}$ & $0.09 \mathrm{a}$ & $0.09 \mathrm{a}$ \\
Epigeal/Roots Ratio & $5.3 \mathrm{~b}$ & $5.7 \mathrm{~b}$ & $7.6 \mathrm{a}$ \\
Epigeal dry matter $(\%)$ & $3.3 \mathrm{~b}$ & $3.7 \mathrm{a}$ & $3.8 \mathrm{a}$ \\
Root dry matter $(\%)$ & $5.2 \mathrm{~b}$ & $5.4 \mathrm{ab}$ & $5.7 \mathrm{a}$ \\
Yield (kg m $\left.{ }^{-2}\right)$ & $4.8 \mathrm{~b}$ & $5.3 \mathrm{~b}$ & $6.9 \mathrm{a}$ \\
WUE (g DW L $\left.{ }^{-1} \mathrm{H}_{2} \mathrm{O}\right)$ & $2.6 \mathrm{~b}$ & $3.1 \mathrm{ab}$ & $3.5 \mathrm{a}$ \\
NUE (g DW g $\left.{ }^{-1} \mathrm{~N}\right)$ & $11.6 \mathrm{~b}$ & $13.6 \mathrm{ab}$ & $14.7 \mathrm{a}$ \\
\hline
\end{tabular}

${ }^{1}$ Results indicate the mean value of four replicates. Data within a row followed by the same letter are not significantly different at $p \leq 0.05$ according to Tukey's test. WUE: water use efficiency. NUE: nitrogen use efficiency.

Similar to fresh biomass, the dry biomass of lettuce plants was positively affected by $\mathrm{GA}_{3}$ treatments. Total dry weight increased significantly only in the plants grown with $10^{-6} \mathrm{M} \mathrm{GA}_{3}$ in the MNS (Table 1), but to a greater extent than fresh weight as it raised by $59.9 \%$. Root dry weight did not show changes due to the presence of $\mathrm{GA}_{3}$ in the MNS, so, the increased total dry weight should be ascribed to the increase of the epigeal part (+67.8\%) (Figure 3). Hence, the dry matter distribution between roots and shoot changed significantly as showed by the E/R ratio that increased from 5.3 of control plants up to 7.6 in the plants grown with $10^{-6} \mathrm{M} \mathrm{GA}_{3}$ (Table 1). The dry matter percentage was positively influenced by $\mathrm{GA}_{3}$ presence in the MNS with a significant difference of 0.5 between control and $10^{-6} \mathrm{M} \mathrm{GA}_{3}$ in both epigeal part and roots (Table 1). 

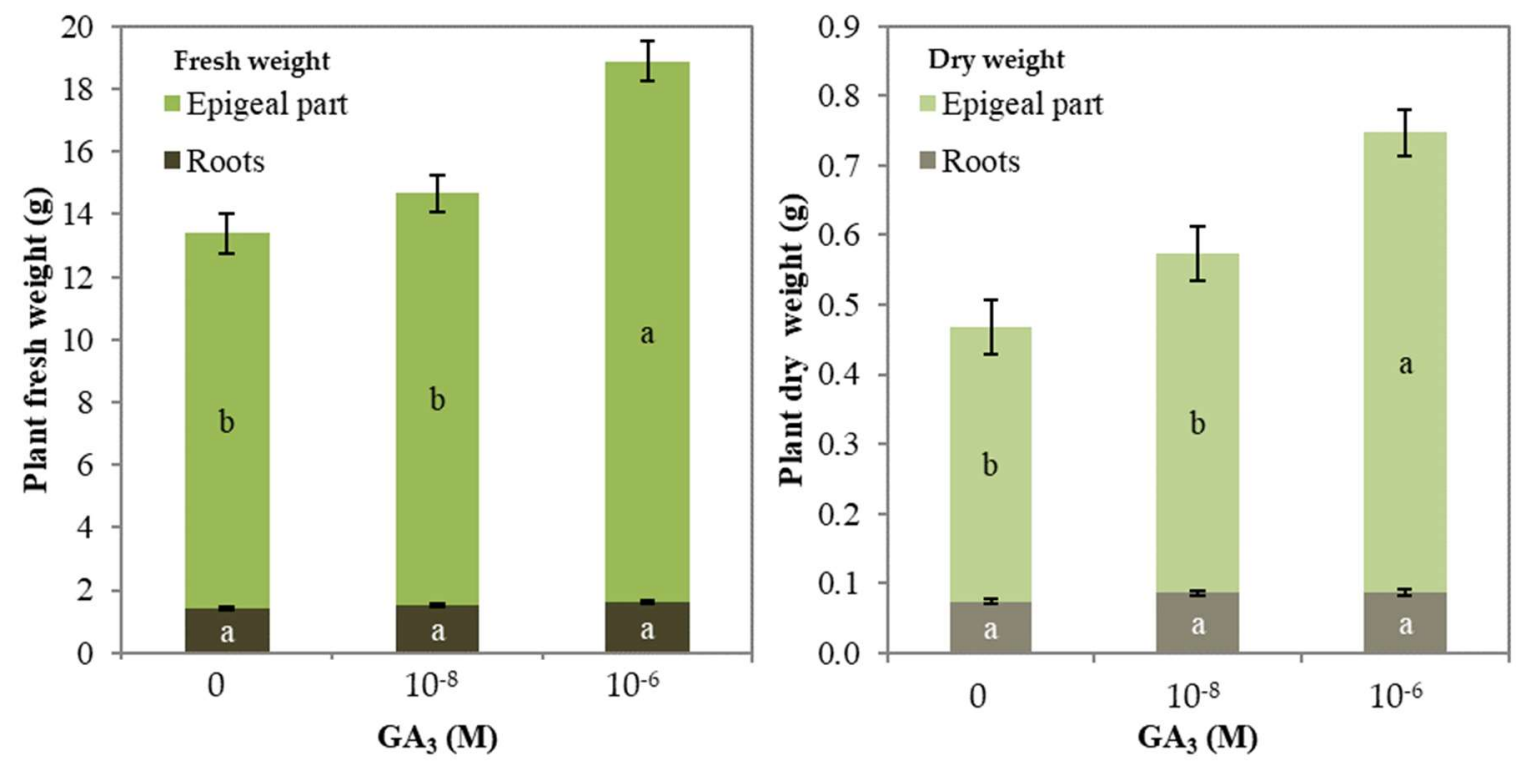

Figure 3. Fresh and dry biomass of leaf lettuce plants grown in nutrient solutions containing different levels of gibberellic acid $\left(\mathrm{GA}_{3}\right)$ (Bars of the same color with different letters are significantly different at $p \leq 0.05$ according to Tukey's test).

The plants of lettuce grown without $\mathrm{GA}_{3}$ yielded $4.8 \mathrm{~kg} \mathrm{~m}^{-2}$; the addition of $\mathrm{GA}_{3}$ to the MNS at the highest concentration $\left(10^{-6} \mathrm{M}\right)$ allowed to yield $2.1 \mathrm{~kg} \mathrm{~m}^{-2}$ more $(+44.6 \%)$ (Table 1$)$. During the crop cycle, the nutrient solution consumed by the plants was periodically restored, and their consumption was measured for each experimental treatment. This allowed calculating the water use efficiency (WUE) and nitrogen use efficiency which were, respectively, $2.6 \mathrm{~g} \mathrm{DW} \mathrm{L}^{-1} \mathrm{H}_{2} \mathrm{O}$ and $11.6 \mathrm{~g} \mathrm{DW} \mathrm{g}^{-1} \mathrm{~N}$ in control plants. WUE and NUE increased with increasing $\mathrm{GA}_{3}$ in the MNS and were significantly higher at the highest concentration $\left(10^{-6} \mathrm{M} \mathrm{GA}_{3} ;+33.4 \%\right.$ and $+28.1 \%$, respectively) (Table 1 ; Figure 4 ).
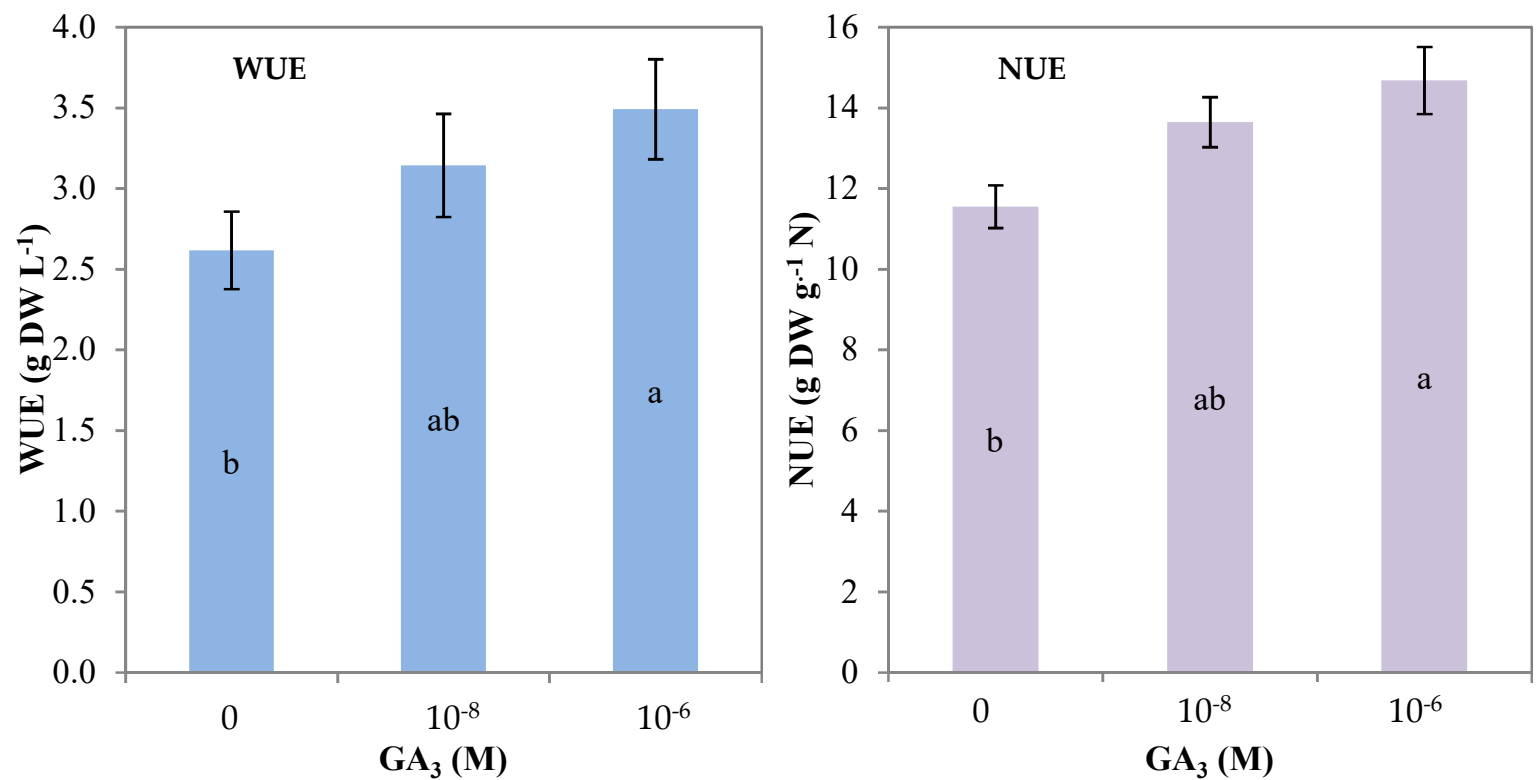

Figure 4. Water use efficiency (WUE) and nitrogen use efficiency (NUE) of leaf lettuce plants grown in nutrient solutions containing different levels of gibberellic acid $\left(\mathrm{GA}_{3}\right)$ (Bars of the same color with different letters are significantly different at $p \leq 0.05$ according to Tukey's test).

Gibberellic acid also affected the leaf characteristics of lettuce plants, which had 8.0 leaves per plant if grown in the absence of $\mathrm{GA}_{3}$ supplementation, whereas, plants grown with $\mathrm{GA}_{3}$ in the MNS 
were leafier, especially at $10^{-6} \mathrm{M} \mathrm{GA}_{3}$ (9.1 leaves plant ${ }^{-1}$ ) (Table 2; Figure 5). GA 3 did not change leaf width but increased leaf area when added to the MNS at $10^{-6} \mathrm{M} \mathrm{GA}_{3}\left(548.3 \mathrm{~cm}^{2}\right.$ plant $^{-1}$ and $60.5 \mathrm{~cm}^{2}$ leaf $^{-1} ;+25.7 \%$ and $+10.9 \%$ than control plants, respectively) (Table 2; Figure 5).

Table 2. Leaf characteristics of leaf lettuce plants grown in nutrient solutions containing different levels of gibberellic acid $\left(\mathrm{GA}_{3}\right)$.

\begin{tabular}{|c|c|c|c|}
\hline & \multicolumn{3}{|c|}{$\mathrm{GA}_{3}(\mathrm{M})$} \\
\hline & 0 & $10^{-8}$ & $10^{-6}$ \\
\hline Number of leaves & $8.0 \mathrm{~b}^{1}$ & $8.3 \mathrm{ab}$ & $9.1 \mathrm{a}$ \\
\hline Leaf width $(\mathrm{cm})$ & $8.8 \mathrm{a}$ & $9.4 \mathrm{a}$ & $8.7 \mathrm{a}$ \\
\hline Leaf area $\left(\mathrm{cm}^{2}\right.$ plant $\left.^{-1}\right)$ & $436.1 \mathrm{~b}$ & $477.8 \mathrm{~b}$ & $548.3 \mathrm{a}$ \\
\hline Leaf area $\left(\mathrm{cm}^{2} \mathrm{leaf}^{-1}\right)$ & $54.5 \mathrm{~b}$ & $57.8 \mathrm{~b}$ & $60.5 \mathrm{a}$ \\
\hline Specific Leaf Area $\left(\mathrm{cm}^{2} \mathrm{~g} \mathrm{DW}^{-1}\right)$ & $704.5 \mathrm{~b}$ & $785.2 \mathrm{ab}$ & $829.1 \mathrm{a}$ \\
\hline Stomatal conductance $\left(\mathrm{mmol} \mathrm{m}{ }^{-2} \mathrm{~s}^{-1}\right)$ & $610.0 \mathrm{~b}$ & $799.0 \mathrm{a}$ & $882.0 \mathrm{a}$ \\
\hline $\mathrm{L}^{*}$ & $54.8 \mathrm{a}$ & $51.0 \mathrm{~b}$ & $50.9 \mathrm{~b}$ \\
\hline$a^{*}$ & $-21.7 \mathrm{a}$ & $-22.0 \mathrm{a}$ & $-21.7 \mathrm{a}$ \\
\hline$b^{*}$ & $39.0 \mathrm{a}$ & $38.2 \mathrm{ab}$ & $37.2 \mathrm{~b}$ \\
\hline Chroma & $44.7 \mathrm{a}$ & $44.1 \mathrm{ab}$ & $43.1 \mathrm{~b}$ \\
\hline $\mathrm{Hue}^{\circ}$ & $119.1 \mathrm{~b}$ & $120.0 \mathrm{ab}$ & $120.3 \mathrm{a}$ \\
\hline Soluble solid content $\left({ }^{\circ}\right.$ Brix $)$ & $2.9 \mathrm{a}$ & $3.1 \mathrm{a}$ & $2.5 \mathrm{a}$ \\
\hline Titratable acidity $\left(\mathrm{mg} 100 \mathrm{~g}^{-1} \mathrm{FW}\right)^{2}$ & $30.7 \mathrm{a}$ & $28.8 \mathrm{a}$ & $25.9 \mathrm{a}$ \\
\hline Ascorbic Acid (mg $\left.100 \mathrm{~g}^{-1} \mathrm{FW}\right)$ & $78.5 \mathrm{a}$ & $53.0 \mathrm{a}$ & $58.0 \mathrm{a}$ \\
\hline $\mathrm{N}^{-\mathrm{NO}^{-}}{ }^{-}\left(\mathrm{mg} \mathrm{kg}^{-1} \mathrm{FW}\right)$ & $2535.0 \mathrm{a}$ & $2305.0 \mathrm{a}$ & $2505.0 \mathrm{a}$ \\
\hline
\end{tabular}

${ }^{1}$ Results indicate the mean value of four replicates. Data within a row followed by the same letter are not significantly different at $p \leq 0.05$ according to Tukey's test. ${ }^{2}$ Titratable acidity expressed as citric acid.

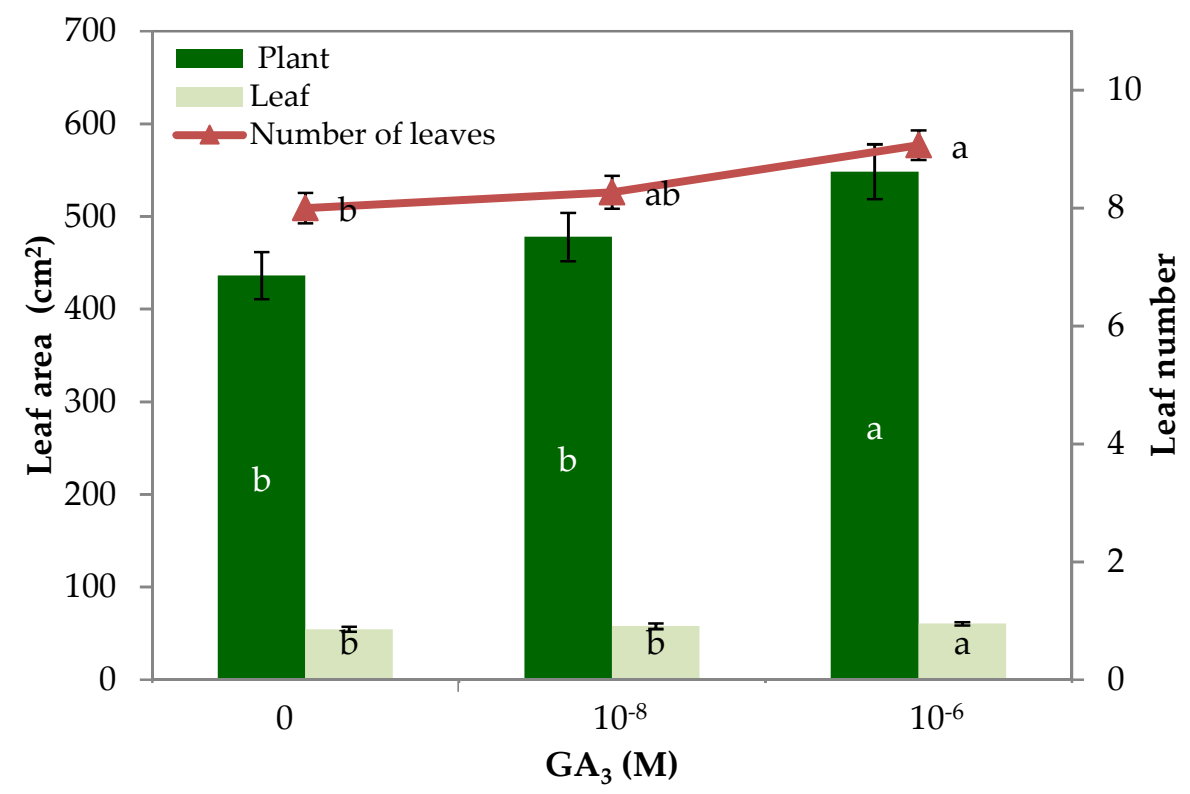

Figure 5. Leaf number and plant and leaf area of leaf lettuce plants grown in nutrient solutions containing different levels of gibberellic acid $\left(\mathrm{GA}_{3}\right)$ (Bars of the same color or points in a line with different letters are significantly different at $p \leq 0.05$ according to Tukey's test).

A significant increase in the specific leaf area (SLA) was found with increasing $\mathrm{GA}_{3}$ concentration in the MNS, showing that $\mathrm{GA}_{3}$ also influenced leaf thickness. SLA was $704.5 \mathrm{~cm}^{2} \mathrm{~g}^{-1} \mathrm{DW}$ in control plants and raised up to $829.1 \mathrm{~cm}^{2} \mathrm{~g}^{-1} \mathrm{DW}$ in the plants grown with $10^{-6} \mathrm{M} \mathrm{GA}_{3}$ in the MNS (Table 2; Figure 6).

The measures of stomatal conductance confirmed that nutrient solution added with $\mathrm{GA}_{3}$ affected leaf characteristics and physiology. In fact, the plants supplied with $\mathrm{GA}_{3}$ had a significant increase 
of stomatal conductance that was on average $840.5 \mathrm{mmol} \mathrm{m}^{-2} \mathrm{~s}^{-1}, 37.8 \%$ higher than control plants $\left(610 \mathrm{mmol} \mathrm{m}^{-2} \mathrm{~s}^{-1}\right.$ ) (Table 2; Figure 6).

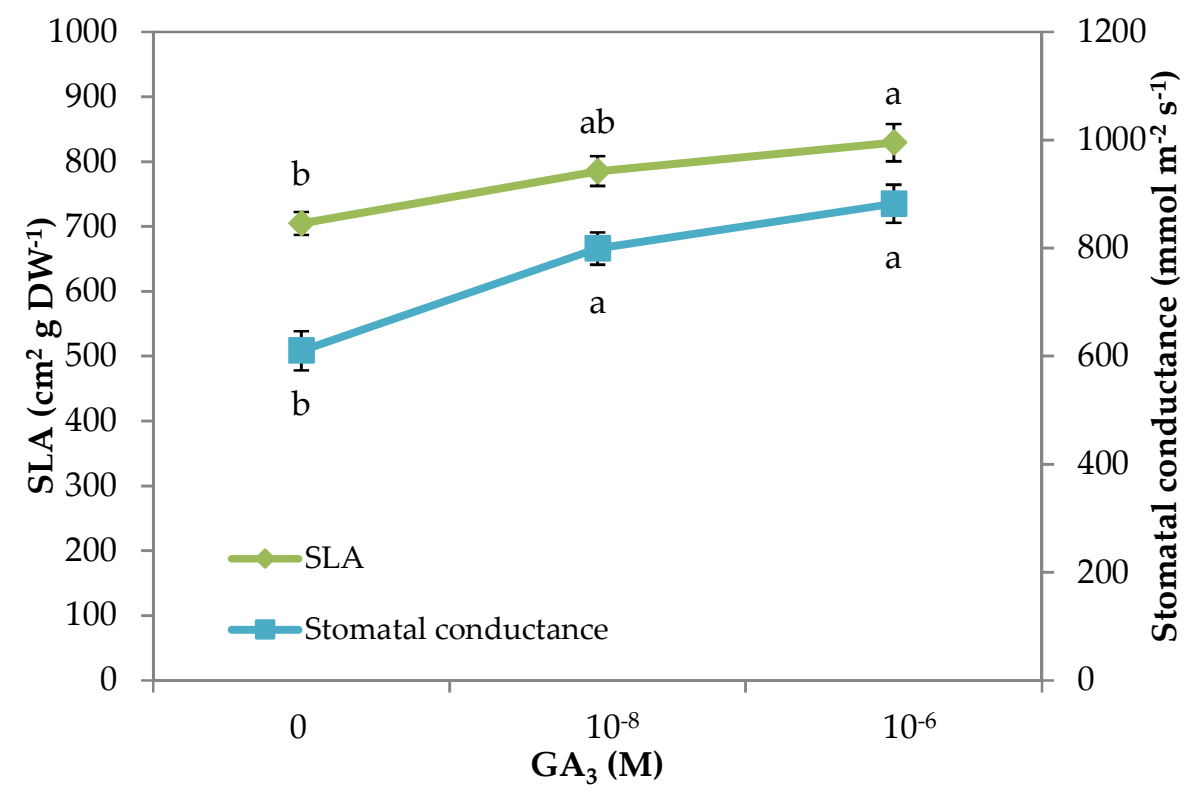

Figure 6. Specific leaf area (SLA) and stomatal conductance of leaf lettuce plants grown in nutrient solutions containing different levels of gibberellic acid $\left(\mathrm{GA}_{3}\right)$ (Points in a line with different letters are significantly different at $p \leq 0.05$ according to Tukey's test).

The plants grown in nutrient solutions added with $\mathrm{GA}_{3}$ showed significant leaf color changes (Table 2). At harvest, the leaves of the plants supplied with $\mathrm{GA}_{3}$ had lower $\mathrm{L}^{*}$ value (lightness) and lower yellow component ( $b^{*}$ value) than those of control plants, resulting in a darker and less vivid (lower chroma) greenish (higher hue angle) color (Table 2).

The quality of leaf lettuce was assessed evaluating soluble solid content (SSC), titratable acidity (TA), nitrate and ascorbic acid content of the leaves, which represent the edible part of this plant (Table 2). SSC, TA, and ascorbic acid content were not significantly influenced by $\mathrm{GA}_{3}$ treatments even if a decreasing trend was found as increasing $\mathrm{GA}_{3}$ dose. This trend was not found in the nitrate content of lettuce leaves, which accumulated $2448.3 \mathrm{mg} \mathrm{kg}^{-1} \mathrm{FW}$ on average.

\subsection{Morpho-Physiological Parameters and Yield of Rocket}

The addition of $\mathrm{GA}_{3}$ in the nutrient solution significantly influenced almost all the examined morpho-physiological parameters of rocket plants.

At harvest, the plants grown with $10^{-6} \mathrm{M} \mathrm{GA}_{3}(24.0 \mathrm{~cm})$ were slightly but significantly higher than control plants $(21.9 \mathrm{~cm})$. Root length showed a decreasing trend with increasing $\mathrm{GA}_{3}$ concentration in the MNS but with no significant difference ( $20 \mathrm{~cm}$ on average) (Table 3$)$.

A similar effect was also found on biomass accumulation in shoot and roots. In fact, plants treated with $10^{-6} \mathrm{M} \mathrm{GA}_{3}$ had a significantly higher total fresh weight $(+40.2 \%)$ than control plants (10.3 g plant $\left.^{-1}\right)$ (Table 3; Figure 7). This increase has to be ascribed to the epigeal part of the plant $(42.9 \%$ more than control with $\left.10^{-6} \mathrm{M} \mathrm{GA}_{3}\right)$, as the root weight did not record significant variations $(0.38 \mathrm{~g}$ on average). The $\mathrm{E} / \mathrm{R}$ ratio increased from 17.9 of control plants up to 27.9 in the plants grown with $10^{-6} \mathrm{M} \mathrm{GA}_{3}$ (Table 3). The effect of $\mathrm{GA}_{3}$ was also significant at the lower concentration with regard to the dry biomass accumulation. But, even in this case, this variation was only due to an increase of the dry weight of the epigeal part. Control plants had an epigeal dry weight of $0.36 \mathrm{~g} \mathrm{DW} \mathrm{plant}^{-1}$ and an $\mathrm{E} / \mathrm{R}$ ratio of 9 . Epigeal dry weight increased up to $0.49 \mathrm{~g} \mathrm{DW} \mathrm{plant}^{-1}(+36.6 \%)$ and $0.58 \mathrm{~g} \mathrm{DW} \mathrm{plant}^{-1}$ $(+59.0 \%)$ for $10^{-8}$ and $10^{-6} \mathrm{M} \mathrm{GA}^{3}$, respectively. E/R reached the highest value with $10^{-6} \mathrm{M} \mathrm{GA}_{3}(12.9)$ 
(Table 3; Figure 7). Shoot and root dry matter percentage were influenced in different ways by the level of $\mathrm{GA}_{3}$ in the nutrient solution. The epigeal dry matter percentage was $5.1 \%$ in control plants and increased significantly adding $\mathrm{GA}_{3}$ in the MNS, independently of the concentration, whereas roots dry matter percentage $\left(10.2 \%\right.$ in control plants) increased significantly only with the highest $\mathrm{GA}_{3}$ level $(12.7 \%)$ (Table 3).

Table 3. Yield and morphological parameters of rocket plants grown in nutrient solutions containing different levels of gibberellic acid $\left(\mathrm{GA}_{3}\right)$.

\begin{tabular}{|c|c|c|c|}
\hline & \multicolumn{3}{|c|}{$\mathrm{GA}_{3}(\mathrm{M})$} \\
\hline & $\mathbf{0}$ & $10^{-8}$ & $10^{-6}$ \\
\hline Plant height (cm) & $21.9 b^{1}$ & $23.1 \mathrm{ab}$ & $24.0 \mathrm{a}$ \\
\hline Root length (cm) & $21.0 \mathrm{a}$ & $19.9 \mathrm{a}$ & $19.1 \mathrm{a}$ \\
\hline \multicolumn{4}{|l|}{ Plant fresh weight } \\
\hline Whole plant (g) & $7.3 \mathrm{~b}$ & $8.4 \mathrm{~b}$ & $10.3 \mathrm{a}$ \\
\hline Epigeal part (g) & $7.0 \mathrm{~b}$ & $8.0 \mathrm{~b}$ & $9.9 \mathrm{a}$ \\
\hline Roots (g) & $0.39 \mathrm{a}$ & $0.39 a$ & $0.36 \mathrm{a}$ \\
\hline Ratio Epigeal/Roots & $17.9 \mathrm{~b}$ & $20.5 b$ & $27.9 \mathrm{a}$ \\
\hline \multicolumn{4}{|l|}{ Plant dry weight } \\
\hline Whole plant (g) & $0.39 \mathrm{~b}$ & $0.53 \mathrm{a}$ & $0.62 \mathrm{a}$ \\
\hline Epigeal part (g) & $0.36 \mathrm{~b}$ & $0.49 \mathrm{a}$ & $0.58 \mathrm{a}$ \\
\hline Roots $(\mathrm{g})$ & $0.04 \mathrm{a}$ & $0.05 \mathrm{a}$ & $0.05 \mathrm{a}$ \\
\hline Ratio Epigeal/Roots & $9.0 \mathrm{~b}$ & $10.8 \mathrm{ab}$ & $12.9 \mathrm{a}$ \\
\hline Epigeal dry matter (\%) & $5.1 \mathrm{~b}$ & $6.1 \mathrm{a}$ & $5.8 \mathrm{a}$ \\
\hline Root dry matter $(\%)$ & $10.2 \mathrm{~b}$ & $11.6 \mathrm{ab}$ & $12.7 \mathrm{a}$ \\
\hline Yield $\left(\mathrm{kg} \mathrm{m}^{-2}\right)$ & $2.8 \mathrm{~b}$ & $3.2 \mathrm{ab}$ & $4.0 \mathrm{a}$ \\
\hline WUE $\left(\mathrm{g}\right.$ DW L $\left.{ }^{-1} \mathrm{H}_{2} \mathrm{O}\right)$ & $2.1 \mathrm{~b}$ & $2.8 \mathrm{a}$ & $2.9 \mathrm{a}$ \\
\hline NUE $\left(g\right.$ DW g $\left.{ }^{-1} \mathrm{~N}\right)$ & $8.8 \mathrm{~b}$ & $11.3 \mathrm{a}$ & $11.5 \mathrm{a}$ \\
\hline
\end{tabular}

\footnotetext{
${ }^{1}$ Results indicate the mean value of four replicates. Data within a row followed by the same letter are not significantly different at $p \leq 0.05$ according to Tukey's test. WUE: water use efficiency. NUE: nitrogen use efficiency.
}

The yield of rocket plants grown without $\mathrm{GA}_{3}$ in the MNS was $2.8 \mathrm{~kg} \mathrm{~m}^{-2}$. The yield of rocket plants increased with the addition of $\mathrm{GA}_{3}$ to the MNS and reached the highest value with the highest $\mathrm{GA}_{3}$ rate $\left(4.0 \mathrm{~kg} \mathrm{~m}^{-2} ;+42.9 \%\right)$ (Table 3$)$.
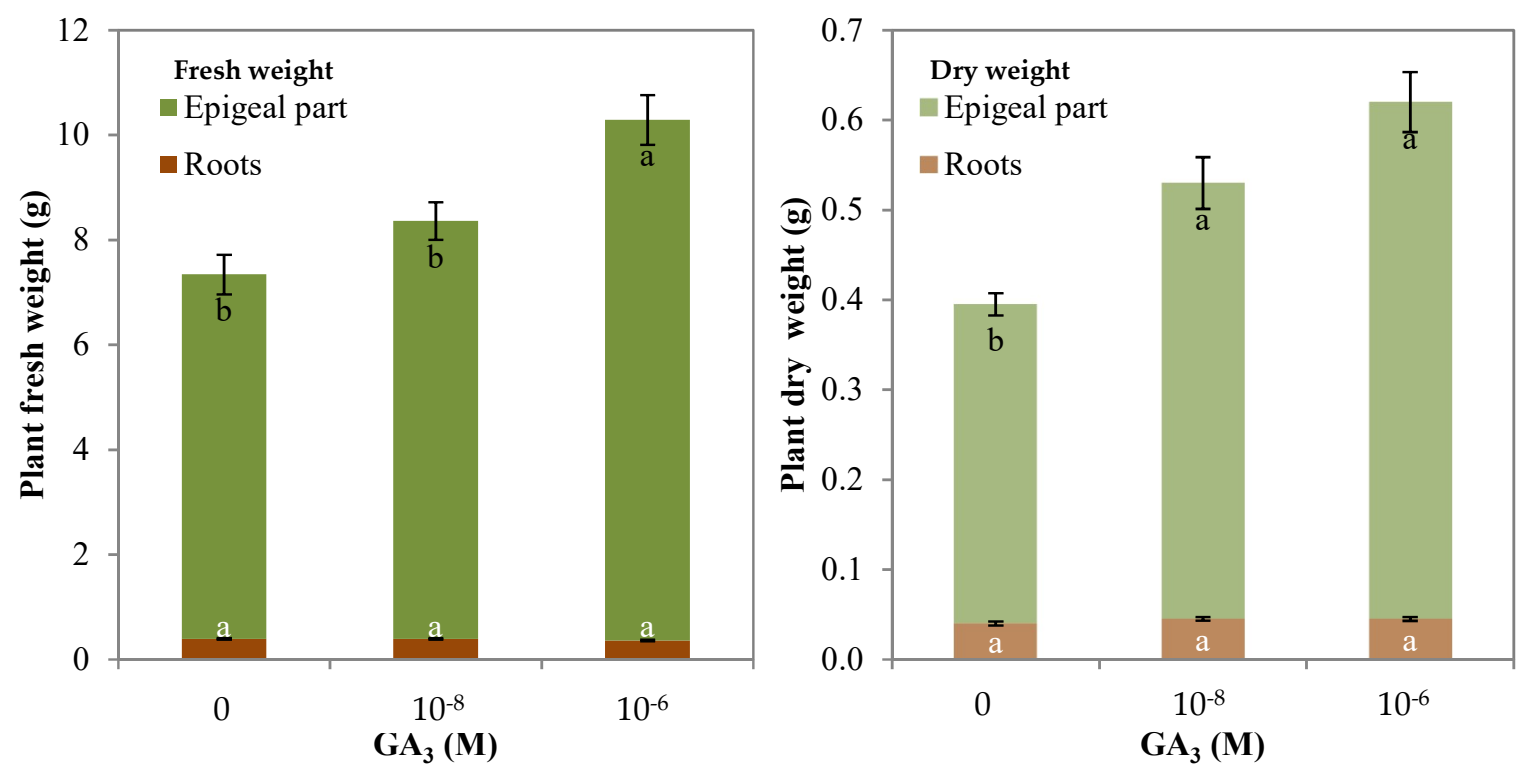

Figure 7. Fresh and dry biomass of rocket plants grown in nutrient solutions containing different levels of gibberellic acid $\left(\mathrm{GA}_{3}\right)$ (Bars of the same color with different letters are significantly different at $p \leq 0.05$ according to Tukey's test). 
A WUE of 2.1 DW L ${ }^{-1} \mathrm{H}_{2} \mathrm{O}$ was calculated for control rocket plants. This parameter increased significantly up to 2.8 (on average) when $\mathrm{GA}_{3}$ was added to the MNS. $\mathrm{GA}_{3}$ was also effective in enhancing NUE of rocket plants that increased from $8.8 \mathrm{~g} \mathrm{DW} \mathrm{g}^{-1} \mathrm{~N}$ in non-treated plants to $11.5 \mathrm{~g} \mathrm{DW} \mathrm{g}^{-1} \mathrm{~N}$, on average, in $\mathrm{GA}_{3}$-treated plants (Table 3; Figure 8)
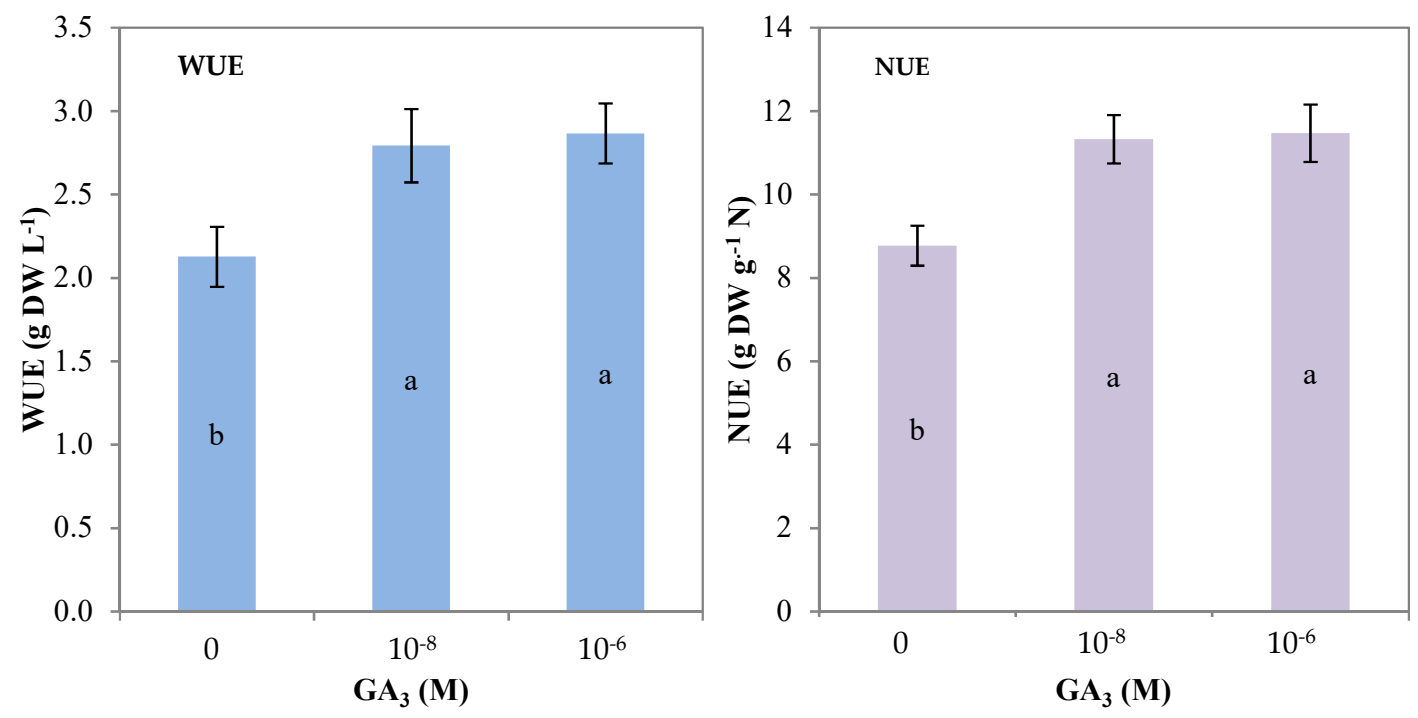

Figure 8. Water use efficiency (WUE) and nitrogen use efficiency (NUE) of rocket plants grown in nutrient solutions containing different levels of gibberellic acid $\left(\mathrm{GA}_{3}\right)$ (Bars of the same color with different letters are significantly different at $p \leq 0.05$ according to Tukey's test).

The morphological traits of rocket leaves were significantly affected by the presence of gibberellic acid in the nutrient solution (Table 4). Plants grown with $10^{-6} \mathrm{M} \mathrm{GA}_{3}$ had a higher number of leaves per plant (10.7) than control plants (9.5). The leaves of the treatment with $10^{-6} \mathrm{M} \mathrm{GA}_{3}$ also differed from those of control plants in the length of their petiole (1.6 cm longer), but no difference was found in leaf blade length (11.4 $\mathrm{cm}$ on average) and in leaf area $\left(10.7 \mathrm{~cm}^{2}\right.$ leaf ${ }^{-1}$ on average). Thus, the higher total leaf area of the plants grown with $\mathrm{GA}_{3}$ in the MNS $\left(112.8 \mathrm{~cm}^{2}\right.$ plant $^{-1},+13.6 \%$ on average $)$ was mostly due to a higher number of leaves per plant (Figure 9).

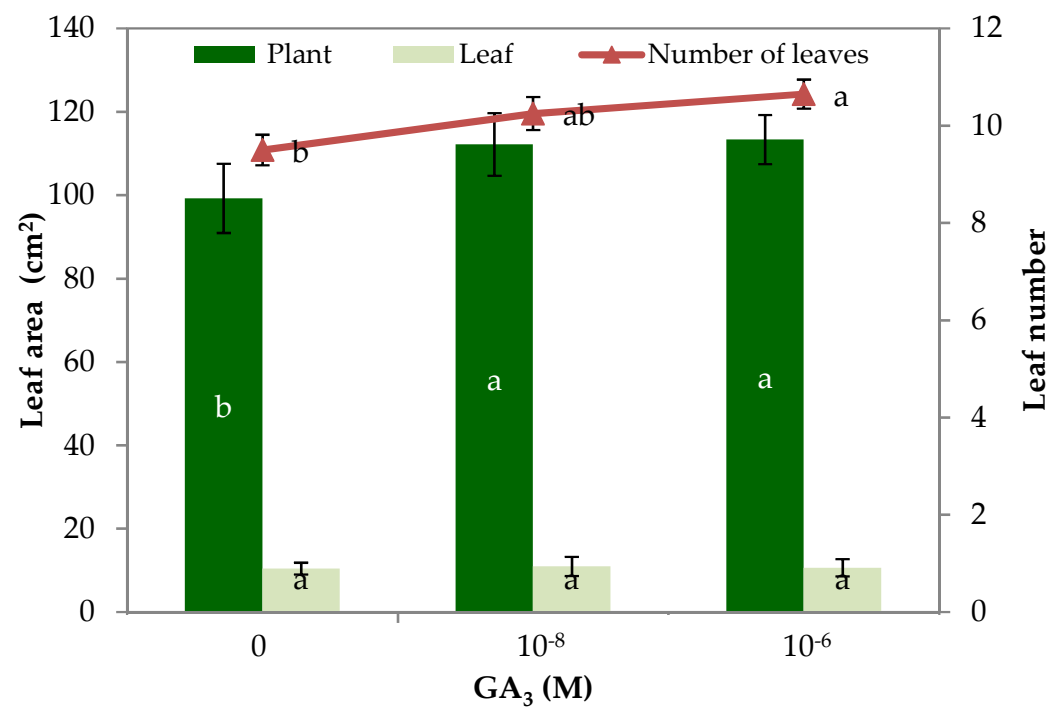

Figure 9. Leaf number and plant and leaf area of rocket plants grown in nutrient solutions containing different levels of gibberellic acid $\left(\mathrm{GA}_{3}\right)$ (Bars of the same color or points of a line with different letters are significantly different at $p \leq 0.05$ according to Tukey's test). 
Specific leaf area was positively affected by the presence of $\mathrm{GA}_{3}$ in the MNS, and the highest value $\left(200.3 \mathrm{~cm}^{2} \mathrm{~g}^{-1} \mathrm{DW}\right)$ was recorded with $10^{-6} \mathrm{M} \mathrm{GA}_{3}$ (Table 4; Figure 10).

The stomatal conductance of rocket leaves grown without $\mathrm{GA}_{3}$ in the MNS was $322.9 \mathrm{mmol} \mathrm{m}^{-2} \mathrm{~s}^{-1}$ (Table 4; Figure 10); MNS supplemented with $\mathrm{GA}_{3}$ induced a significant increase of the stomatal conductance $\left(533.8 \mathrm{mmol} \mathrm{m}^{-2} \mathrm{~s}^{-1}\right.$ on average), that had a positive linear correlation with SLA $\left(R^{2}=0.901\right)$.

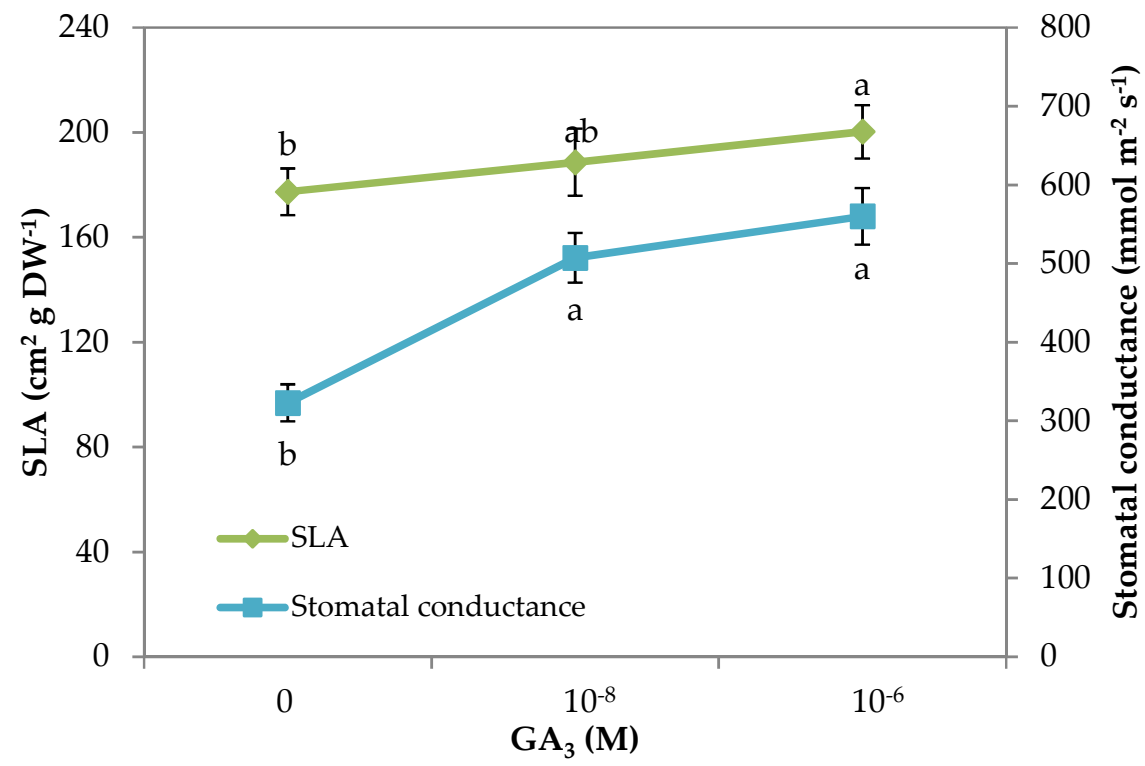

Figure 10. Specific leaf area (SLA) and stomatal conductance of rocket plants grown in nutrient solutions containing different levels of gibberellic acid $\left(\mathrm{GA}_{3}\right)$ (Points of a line with different letters are significantly different at $p \leq 0.05$ according to Tukey's test).

The color of rocket leaves at harvest changed significantly with the highest $\mathrm{GA}_{3}$ concentration that affected $\mathrm{L}^{*}$ and $\mathrm{a}^{*}$ parameters; $\mathrm{L}^{*}$ increased, whereas $\mathrm{a}^{*}$ decreased with increasing $\mathrm{GA}_{3}$ concentration in the MNS, corresponding to a darker greenish color (Table 4).

Table 4. Leaf characteristics of rocket plants grown in nutrient solutions containing different levels of $\mathrm{GA}_{3}$.

\begin{tabular}{|c|c|c|c|}
\hline & \multicolumn{3}{|c|}{$\mathrm{GA}_{3}(\mathrm{M})$} \\
\hline & 0 & $10^{-8}$ & $10^{-6}$ \\
\hline Number of leaves & $9.5 b^{1}$ & $10.3 \mathrm{ab}$ & $10.7 \mathrm{a}$ \\
\hline Leaf blade length (cm) & $11.1 \mathrm{a}$ & $11.6 \mathrm{a}$ & $11.6 \mathrm{a}$ \\
\hline Petiole length $(\mathrm{cm})$ & $8.7 \mathrm{a}$ & $8.8 \mathrm{~b}$ & $10.2 \mathrm{a}$ \\
\hline Leaf area $\left(\mathrm{cm}^{2}\right.$ plant $\left.^{-1}\right)$ & $99.2 \mathrm{~b}$ & $112.2 \mathrm{a}$ & $113.3 \mathrm{a}$ \\
\hline Leaf area $\left(\mathrm{cm}^{2} \mathrm{leaf}^{-1}\right)$ & $10.4 \mathrm{a}$ & 10.9 a & $10.6 \mathrm{a}$ \\
\hline Specific Leaf Area $\left(\mathrm{cm}^{2} \mathrm{~g}^{-1} \mathrm{DW}\right)$ & $177.4 \mathrm{~b}$ & $188.6 \mathrm{ab}$ & $200.3 \mathrm{a}$ \\
\hline Stomatal conductance $\left(\mathrm{mmol} \mathrm{m} \mathrm{m}^{-2} \mathrm{~s}^{-1}\right)$ & $322.9 \mathrm{~b}$ & $507.4 \mathrm{a}$ & $560.1 \mathrm{a}$ \\
\hline $\mathrm{L}^{*}$ & $44.7 \mathrm{a}$ & $43.5 \mathrm{ab}$ & $43.1 \mathrm{~b}$ \\
\hline$a^{*}$ & $-19.4 b$ & $-19.1 a b$ & $-18.6 \mathrm{a}$ \\
\hline$b^{*}$ & $26.2 \mathrm{a}$ & $25.5 \mathrm{a}$ & $24.3 \mathrm{a}$ \\
\hline Chroma & $32.6 \mathrm{a}$ & $31.8 \mathrm{a}$ & $30.6 \mathrm{a}$ \\
\hline $\mathrm{Hue}^{\circ}$ & $126.8 \mathrm{a}$ & $127.2 \mathrm{a}$ & $127.5 \mathrm{a}$ \\
\hline Soluble solid content $\left({ }^{\circ}\right.$ Brix $)$ & $5.8 \mathrm{a}$ & $5.2 \mathrm{a}$ & $5.4 \mathrm{a}$ \\
\hline Titratable acidity $\left(\mathrm{mg} 100 \mathrm{~g}^{-1} \mathrm{FW}\right)^{2}$ & $46.1 \mathrm{a}$ & $44.8 \mathrm{a}$ & $44.8 \mathrm{a}$ \\
\hline Ascorbic Acid (mg $\left.100 \mathrm{~g}^{-1} \mathrm{FW}\right)$ & $173.0 \mathrm{~b}$ & $221.0 \mathrm{a}$ & $218.0 \mathrm{a}$ \\
\hline $\mathrm{N}^{-N^{\prime} 3^{-}}\left(\mathrm{mg} \mathrm{kg}^{-1} \mathrm{FW}\right)$ & $2714.9 \mathrm{a}$ & $2364.9 \mathrm{ab}$ & $2069.9 \mathrm{~b}$ \\
\hline
\end{tabular}
${ }^{1}$ Results indicate the mean value of four replicates. Data within a row followed by the same letter are not significantly
different at $p \leq 0.05$ according to Tukey's test. ${ }^{2}$ Titratable acidity expressed as citric acid. 
Rocket leaf quality was influenced by $\mathrm{GA}_{3}$ treatments only regarding ascorbic acid and nitrate

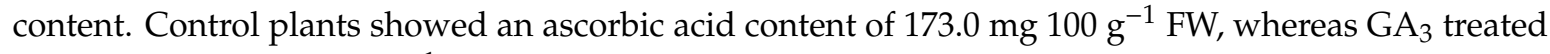
leaves had $219.5 \mathrm{mg} 100 \mathrm{~g} \mathrm{~g}^{-1} \mathrm{FW}$ on average (Table 4). On the contrary, nitrate content decreased with increasing $\mathrm{GA}_{3}$ level in the MNS and ranged from $2714.9 \mathrm{mg} \mathrm{kg}^{-1} \mathrm{FW}$ (control) to $2069.9 \mathrm{mg} \mathrm{kg}^{-1} \mathrm{FW}$ $\left(10^{-6} \mathrm{M} \mathrm{GA}_{3}\right)$.

\subsection{Principal Components Analysis}

The results of PCA showed two principal components (PCs) with eigenvalues higher than 1 (Table 5), accounting for $77.90 \%$ and $17.86 \%$ of the total variance, respectively. This indicated that the initial 29 variables could be expressed as a linear combination of two PCs, explaining $95.76 \%$ of the total variance. PC1 was mainly related to plant height, root length, whole plant FW, epigeal part FW, root FW, E/R FW, root DW, E/R DW, epigeal and root dry matter percentage, yield, NUE, leaf number, plant and leaf area, SLA, stomatal conductance, leaf color components, SSC, TA and ascorbic acid content; PC2 was related to whole plant and epigeal part DW, WUE and nitrate (Table 5).

Table 5. Correlation of variables to the factors of the principal components analysis (PCA) based on factor loadings.

\begin{tabular}{|c|c|c|}
\hline Variables & PC1 & PC2 \\
\hline Plant height & 0.766 & 0.412 \\
\hline Root length & 0.990 & -0.137 \\
\hline Whole plant fresh weight & 0.932 & 0.339 \\
\hline Epigeal part fresh weight & 0.905 & 0.398 \\
\hline Root fresh weight & 0.999 & -0.049 \\
\hline E/R fresh weight & -0.874 & 0.439 \\
\hline Whole plant dry weight & 0.465 & 0.881 \\
\hline Epigeal part dry weight & 0.311 & 0.943 \\
\hline Roots dry weight & -0.982 & 0.179 \\
\hline E/R dry weight & -0.823 & 0.554 \\
\hline Epigeal dry weight & -0.922 & 0.340 \\
\hline Root dry weight & -0.954 & 0.296 \\
\hline Yield & 0.905 & 0.398 \\
\hline Water Use Efficiency & 0.655 & 0.729 \\
\hline Nitrogen Use Efficiency & 0.797 & 0.566 \\
\hline Leaf No. & -0.818 & 0.564 \\
\hline Plant area & 0.999 & 0.032 \\
\hline Leaf area & 0.998 & -0.050 \\
\hline Specific Leaf Area & 0.999 & -0.002 \\
\hline Stomatal conductance & 0.863 & 0.480 \\
\hline $\mathrm{L}^{*}$ & 0.911 & -0.342 \\
\hline$a^{*}$ & -0.982 & 0.035 \\
\hline$b^{*}$ & 0.973 & -0.213 \\
\hline Chroma & 0.973 & -0.216 \\
\hline Hue & -0.975 & 0.160 \\
\hline Soluble solid content & -0.989 & -0.035 \\
\hline Titratable acidity & -0.999 & -0.045 \\
\hline Ascorbic acid & -0.968 & 0.184 \\
\hline $\mathrm{N}-\mathrm{NO}_{3}^{-}$ & 0.151 & -0.693 \\
\hline
\end{tabular}

Values in bold within the same factor indicate the variable with the largest correlation.

The projection of the original variables on the plane of the two PCs could clearly demonstrate such a relationship, as reported in the plot of loadings (Figure 11a). The discrimination of the various $\mathrm{GA}_{3}$ concentrations supplied to leaf lettuce and rocket plants can be seen in the plot of scores (Figure 11b), where two clusters could be visibly distinguished. Lettuce scores were located in the positive part of the PC1 axis and clearly separated from those of rocket, located in the negative part of the PC1 axis. The scores of $0 \mathrm{GA}_{3}$ had the lowest $\mathrm{PC} 2$ values for both leafy vegetables. The response of lettuce 
and rocket differed when treated with $\mathrm{GA}_{3}$, as the scores of treated rocket plants had both positive values of $\mathrm{PC} 2$, whereas only lettuce supplied with $10^{-6} \mathrm{M} \mathrm{GA}_{3}$ was in the positive part of PC2 axis (first quadrant). Combining the data from the plot of loadings and scores, it can be concluded that $\mathrm{GA}_{3}$ doses influenced the tested species in different ways (Figure 11a,b). Lettuce was related to all parameters positively related to $\mathrm{PC} 1$, whereas rocket was related to all parameters negatively related to PC1. The increase of $\mathrm{GA}_{3}$ in the nutrient solution was positively related to plant dry weight, WUE, leaf number, E/R ratios, NUE, stomatal conductance, plant height, plant fresh weight and yield, and negatively related to nitrate content, $\mathrm{L}^{*}$ and chrome.
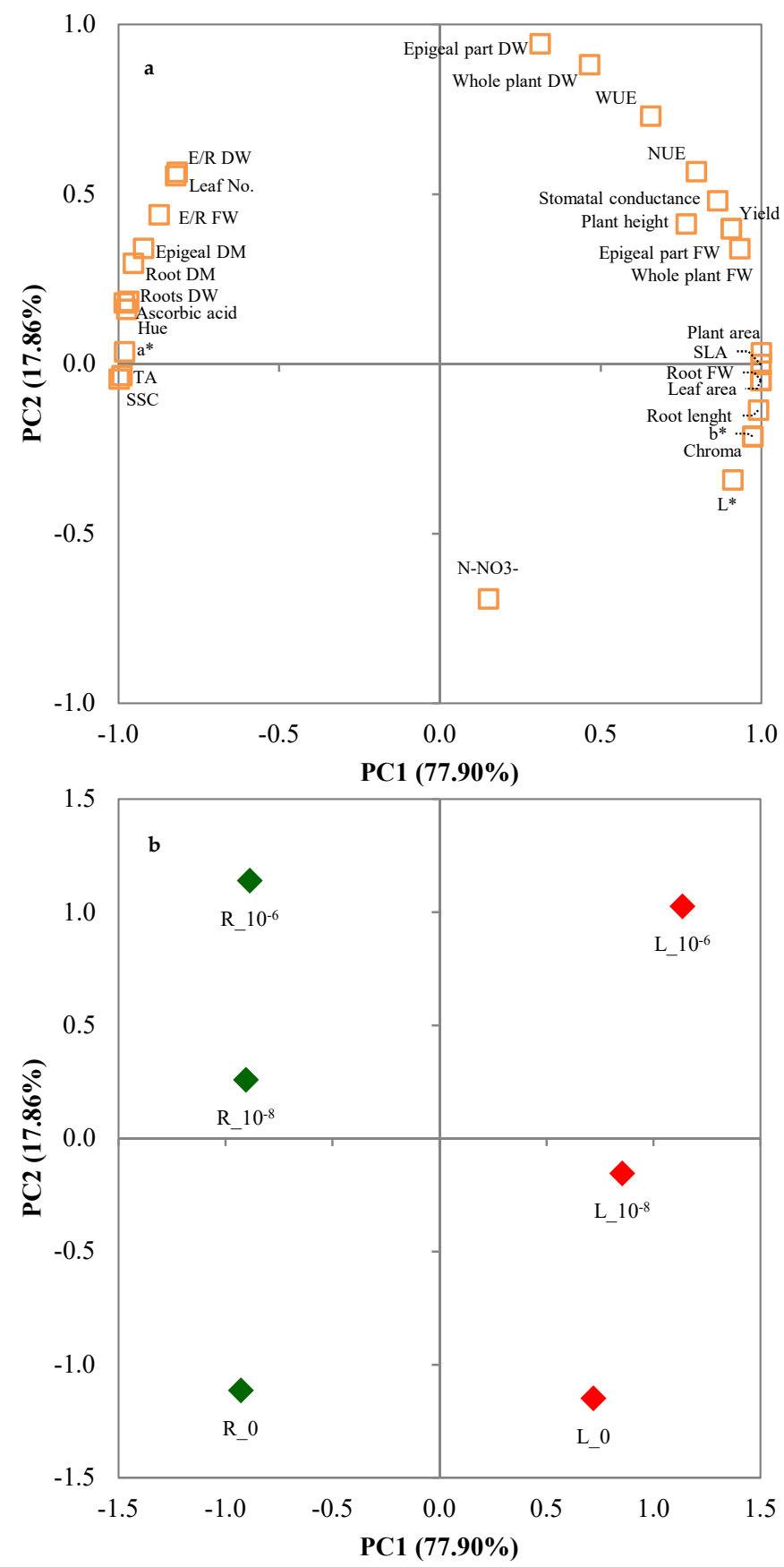

Figure 11. Plot of (a) loadings (morpho-physiological and quality characteristics of lettuce and rocket plants) and (b) scores (trials) formed by the two principal components from the PCA analysis. L_0, L_1 $10^{-8}$ and L_10 $0^{-6}$ : lettuce cultivated in nutrient solutions with $0,10^{-8}$ and $10^{-6} \mathrm{M} \mathrm{GA}_{3}$, respectively; R_0, R_10 $10^{-8}$ and $\mathrm{R} \_10^{-6}$ : rocket cultivated in nutrient solutions with $0,10^{-8}$ and $10^{-6} \mathrm{M}$ $\mathrm{GA}_{3}$, respectively. 


\section{Discussion}

Currently, GAs are used commercially to enhance morpho-physiological and yield characteristics of many vegetable and ornamental crops $[9,46]$. Many experiments have been carried out to study the effect of spraying exogenous gibberellic acid $\left(\mathrm{GA}_{3}\right)$ at very low concentrations on various crops $[24,30,32,33,36,38,40,41]$, showing that hormone requirement, relative concentrations, and responses may vary for different species and different growth stages [29]. Foliar application of gibberellins has been generally adopted because these hormones are naturally synthetized in young leaves and from there are subsequently transported throughout the plant moving both acropetally and basipetally [47]. However, roots have been demonstrated to be a site of interconversion of gibberellin produced in shoots rather than a primary source [48]; in the roots, some deactivated gibberellins are converted to active GAs precursor and exported back to the shoots. In this experiment, we tested the feasibility of suppling low levels of $\mathrm{GA}_{3}$ to leaf lettuce and rocket plants through the mineral nutrient solution of a floating system and evaluated their effects on growth and quality.

Both leaf lettuce and rocket were shown to be sensitive to exogenous $\mathrm{GA}_{3}$ supplementation even if with a different response to tested levels. The marketability of plants was lost when $10^{-4} \mathrm{M} \mathrm{GA}_{3}$ was added to the mineral nutrient solution. The leafy vegetables grown with this rate of $\mathrm{GA}_{3}$ in the MNS responded with accelerated stem elongation that was accompanied by pale green and narrowed leaves in lettuce plants and by a relatively rapid flower development in rocket plants. It is well known that $\mathrm{GA}_{3}$ treatments promote cell division and cell enlargements that may result in stem elongation [49-52] and that exogenous gibberellins can break the rosette or enhance and control the flowering of rosette plants by means of rapid enlargement of already differentiated tissues [53]. GAs promote cytogenesis and cell elongation in stems and can also stimulate flowering when they reach the shoot apex $[54,55]$. Below $10^{-4} \mathrm{M} \mathrm{GA}_{3}$, the presence of $\mathrm{GA}_{3}$ in the MNS was effective as a plant growth promoter and yield enhancer, especially at $10^{-6} \mathrm{M} \mathrm{GA}_{3}$. This level of $\mathrm{GA}_{3}$ increased significantly plant height in the tested leafy vegetables but to a different extent for lettuce and rocket. Plant hormones, such as gibberellins, brassinosteroids, and strigolactones play an important role in plant growth and development [56]. The cytological basis of GA-mediated regulation of plant height and organ size involves the promotion of both cell elongation and cell division $[57,58]$.

$\mathrm{GA}_{3}$ treatments also enhanced other morphological and physiological traits, with superimposable trends in both leafy vegetables. Lettuce and rocket treated with $10^{-6} \mathrm{M} \mathrm{GA}_{3}$ showed an increase of total fresh biomass accumulation of $41.1 \%$ and $40.2 \%$, respectively, as compared to controls. This increase was due to the increase of the epigeal part in both species ( $44.5 \%$ and $42.9 \%$, respectively). This pattern was also found for dry biomass: the total dry biomass of plants increased by $59.9 \%$ and $59.0 \%$, and the epigeal biomass by $67.8 \%$ and $62.0 \%$ for lettuce and rocket, respectively, as compared to controls. Hence, the addition of $10^{-6} \mathrm{M} \mathrm{GA}_{3}$ affected resource repartition in the plants, promoting the growth of the aerial part as shown by the increase of the shoot:root ratio in both species. Gibberellic acid has been shown to exert a promoting effect of biomass production $[20,23]$ of vegetative parts through the promotion of DNA, RNA, and protein synthesis [59-63] and ribose and polyribosome multiplication [64]. Biomass accumulation in $\mathrm{GA}_{3}$ treated plants also follows from improved enzyme activity [65-68] and increased membrane permeability $[69,70]$ that might facilitate uptake and use of mineral nutrients [33,68,71,72] and transport of photosynthates [73-76].

Moreover, GAs play important roles in regulating biomass allocation [77]. Genotypes of many species with high levels of endogenous GAs are characterized by higher leaf: root or shoot: root ratios compared to those with low levels of endogenous GAs [78]. Similarly, exogenous $\mathrm{GA}_{3}$ may markedly change morphological traits of plants and promote biomass allocation to leaves. Sugiura et al. [79] found that the plants with high levels of endogenous GAs showed morphologies similar to those sprayed with $\mathrm{GA}_{3}$ and highlighted a close relationship among morphological and physiological traits, thus confirming that this phytohormone is involved in the regulation of biomass allocation [80].

Many authors have shown that plant growth regulators can influence the phenotype, growth, and development of plants by changing hormonal content and their balance, which subsequently regulate 
crop yield [81-85]. In our experiment, we found that the increase of biomass accumulation and the changes in biomass allocation caused by exogenous $\mathrm{GA}_{3}$ supply $\left(10^{-6} \mathrm{M} \mathrm{GA}_{3}\right)$, positively affected the yield of leaf lettuce and rocket with an increase of $44.6 \%$ and $42.9 \%$, respectively.

$\mathrm{GA}_{3}$ treated plants show enhanced carbonic anhydrase (CA) activity [86]. This enzyme has a role in photosynthetic $\mathrm{CO}_{2}$ fixation [87] as it takes part in the hydration of $\mathrm{CO}_{2}$ and is strictly associated with chloroplast [88]. This may guarantee enough supply of $\mathrm{CO}_{2}$ at the site of its fixation, thus determining the high net photosynthetic rate and, consequently, high dry mass accumulation $[86,89]$. Yuan and $\mathrm{Xu}[90]$ reported that the increased net photosynthetic rate found after the application of $\mathrm{GA}_{3}$ to broad bean leaves was accompanied by an increase in stomatal conductance and a decrease in intercellular $\mathrm{CO}_{2}$ partial pressure. These effects of $\mathrm{GA}_{3}$ supplementation could be very beneficial on leafy vegetables grown at high plant density in hydroponic floating systems, where self-shadowing and slow air movement inside the canopy could negatively affect light interception and $\mathrm{CO}_{2}$ availability. The positive influence of $\mathrm{GA}_{3}$ on CA activity and photosynthetic rate of lettuce and rocket plant could be indirectly confirmed by the increased stomatal conductance and the greater dry mass accumulation that we recorded in this trial.

The higher photosynthetic activity should also be ascribed to the morphological modification of lettuce and rocket plants grown with $10^{-6} \mathrm{M} \mathrm{GA}_{3}$. Exogenous $\mathrm{GA}_{3}$ supplied via the MNS increased leaf number and stimulated cell enlargement and leaf expansion, thus also affecting total leaf area and SLA. In addition, $\mathrm{GA}_{3}$ treatments also influenced leaf color that showed a lower $\mathrm{L}^{*}, \mathrm{~b}^{*}$, and chroma values and a higher hue angle than control plants. These parameters have a strong correlation with the chlorophyll content of leaves [91,92]. Hence, $\mathrm{GA}_{3}$ supply could have also determined an increase of photosynthetic pigments. The response of chlorophyll content to $\mathrm{GA}_{3}$ application is still controversial. Both decreases [93-95] and increases [94,96] in chlorophyll content were reported after the application of $\mathrm{GA}_{3}$. Wheeler and Humphies [95] suggested that increases in leaf area caused by $\mathrm{GA}_{3}$ may lead to chlorophyll dilution rather than to increased chlorophyll content. Probably these variations of chlorophyll content may depend on $\mathrm{GA}_{3}$ dose and timing of application.

The combined positive effect of $\mathrm{GA}_{3}$ on both stomatal conductance and leaf area development was revealed in terms of improved water use efficiency. Leaf stomatal conductance estimates rates of transpiration and gas exchange through leaf stomata. Maggio et al. [39] reported that the application of $\mathrm{GA}_{3}$ decreased stomatal resistance and improved efficiency of water use in tomato plants. The mechanism that links $\mathrm{GA}_{3}$ application with stomata opening is not well known; nevertheless, the increase of stomatal conductance due to $\mathrm{GA}_{3}$ has been related to the higher accumulation of carbohydrates and potassium in guard cells of treated plants, that may influence speed and degree of stomata opening [97]. Even if the higher stomatal conductance of treated plants determines an increase of transpiration rates and water consumption, it also promotes gas exchange and photosynthetic $\mathrm{CO}_{2}$ assimilation, thus increasing dry matter accumulation and WUE. In hydroponic floating systems, a high transpiration rate is not a problem as plants float on MNS. Thus, a higher stomatal conductance induced by $\mathrm{GA}_{3}$ treatments could only be beneficial for this cultivation technique.

$\mathrm{GA}_{3}$ affects nitrogen metabolism and nitrogen redistribution in plants and increases N-use efficiency (NUE) by improving better utilization of $\mathrm{N}$ [40]. In our work, we found an increase of NUE in treated plants of leaf lettuce and rocket $\left(+27.1 \%\right.$ and $+30.7 \%$, respectively, with $10^{-6} \mathrm{M}$ $\mathrm{GA}_{3}$ ). The enhanced growth stimulated by exogenous $\mathrm{GA}_{3}$ increases the nitrogen needs of the plants. $\mathrm{GA}_{3}$ application may help to redistribute assimilates towards shoot apex and young leaves, aiding in the utilization of nitrogen and thus resulting in increased yield [40]. Moreover, the improvement in nitrogen utilization was possibly mediated by the effect of $\mathrm{GA}_{3}$ on nitrate reductase activity $[85,98]$, as confirmed by the reduction of nitrate accumulation in rocket treated with $10^{-6} \mathrm{M} \mathrm{GA}_{3}$. This level of $\mathrm{GA}_{3}$ might have affected nitrate reductase, but to a different extent in the tested leafy vegetables. The increased activity of this enzyme could have determined a reduction of nitrate accumulation in rocket during plant growth, while leaf lettuce plants could have not reduced the nitrate content during growth for a more efficient translocation from roots to leaves. SSC and TA were not significantly 
affected by $\mathrm{GA}_{3}$, whereas ascorbic acid content showed opposite trends in the tested leafy vegetables: It slightly decreased in lettuce and increased in rocket with increasing $\mathrm{GA}_{3}$ levels. The concentration of vitamin $C$ in some fruits and vegetables may be related to nitrogen availability, and this relationship may vary depending on genus, climate, and other factors $[99,100]$. It seems that to maintain ascorbic acid synthesis, leafy vegetables need to have sufficient $\mathrm{N}$ supply [101,102]. Thus, $\mathrm{GA}_{3}$ treatments could have increased nitrogen needs of plants, which, in turn, have redistributed it to different biochemical processes.

The PCA analysis showed that lettuce and rocket were positively affected by $\mathrm{GA}_{3}$ treatments even if with different extents for different parameters. Moreover, plants response to $\mathrm{GA}_{3}$ treatment was shown to be species and dose-dependent, thus confirming that hormone requirement, relative concentrations, and responses may vary for different species [29].

These findings suggest the need to deepen the research on the dose and methods of application of $\mathrm{GA}_{3}$ to vegetables according to the cultivation system. Moreover, $\mathrm{GA}_{3}$ treatment during plant growth might also exert some effects on post-harvest characteristics of vegetables that could be worth to better investigating.

\section{Conclusions}

Growth and biomass accumulation of leaf lettuce and rocket plants were influenced by $\mathrm{GA}_{3}$ level in the nutrient solution of a hydroponic floating system. The highest rate of $\mathrm{GA}_{3}\left(10^{-4} \mathrm{M}\right)$ had a negative impact on the crops as it strongly modified their morphology so that they lose marketability before harvest. Below this level, the presence of $\mathrm{GA}_{3}$ in the MNS was effective as a plant growth promoter and yield enhancer, especially at $10^{-6} \mathrm{M} \mathrm{GA}_{3}$. Various morphological and physiological traits were enhanced by $\mathrm{GA}_{3}$ treatments (biomass accumulation, leaf expansion, stomatal conductance, WUE, NUE, etc.), with similar trends registered for both lettuce and rocket. Finally, this investigation suggested that the addition of $10^{-6} \mathrm{M} \mathrm{GA}_{3}$ to the nutrient solution of a hydroponic floating system can promote growth and quality of lettuce and rocket plants.

Author Contributions: Conceptualization, A.M. (Alessandro Miceli), A.M. (Alessandra Moncada) and F.V.; Data curation, A.M. (Alessandro Miceli), A.M. (Alessandra Moncada) and F.V.; Formal analysis, A.M. (Alessandro Miceli); Investigation, A.M. (Alessandro Miceli), A.M. (Alessandra Moncada), L.S. and F.V.; Methodology, A.M. (Alessandro Miceli), A.M. (Alessandra Moncada) and F.V.; Supervision, A.M. (Alessandro Miceli); Validation, A.M. (Alessandro Miceli), Writing_original draft, A.M. (Alessandro Miceli) and F.V.; Writing—review and editing, A.M. (Alessandro Miceli) and A.M. (Alessandra Moncada).

Funding: This research received no external funding.

Conflicts of Interest: The authors declare no conflict of interest.

\section{References}

1. Lynch, M.F.; Tauxe, R.V.; Hedberg, C.W. The growing burden of foodborne outbreaks due to contaminated fresh produce: Risks and opportunities. Epidemiol. Infect. 2009, 137, 307-315. [CrossRef] [PubMed]

2. Settanni, L.; Miceli, A.; Francesca, N.; Cruciata, M.; Moschetti, G. Microbiological investigation of Raphanus sativus L. grown hydroponically in nutrient solutions contaminated with spoilage and pathogenic bacteria. Int. J. Food Microbiol. 2013, 160, 344-352. [CrossRef] [PubMed]

3. Tomasi, N.; Pinton, R.; Dalla Costa, L.; Cortella, G.; Terzano, R.; Mimmo, T.; Scampicchio, M.; Cesco, S. New 'solutions' for floating cultivation system of ready-to-eat salad: A review. Trends Food Sci. Technol. 2015, 46, 267-276. [CrossRef]

4. Khan, I.; Tango, C.N.; Miskeen, S.; Lee, B.H.; Oh, D.-H. Hurdle technology: A novel approach for enhanced food quality and safety-A review. Food Control 2017, 73, 1426-1444. [CrossRef]

5. Miceli, A.; Settanni, L. Influence of agronomic practices and pre-harvest conditions on the attachment and development of Listeria monocytogenes in vegetables. Ann. Microbiol. 2019, 69, 185-199. [CrossRef] 
6. Soerjomataram, I.; Oomen, D.; Lemmens, V.; Oenema, A.; Benetou, V.; Trichopoulou, A.; Coebergh, J.W.; Barendregt, J.; de Vries, E. Increased consumption of fruit and vegetables and future cancer incidence in selected European countries. Eur. J. Cancer 2010, 46, 2563-2580. [CrossRef] [PubMed]

7. Karam, M.C.; Petit, J.; Zimmer, D.; Djantou, E.B.; Scher, J. Effects of drying and grinding in production of fruit and vegetable powders: A review. J. Food Eng. 2016, 188, 32-49. [CrossRef]

8. Chakraborty, I.; Chattopadhyay, A. Pre- and Post-Harvest Losses in Vegetables. In Advances in Postharvest Technologies of Vegetable Crops; Singh, B., Singh, S., Koley, T.K., Eds.; CRC Press Taylor \& Francis: Boca Raton, FL, USA, 2018.

9. Lee, I.J. Practical application of plant growth regulator on horticultural crops. J. Hort. Sci. 2003, 10, $211-217$.

10. Miceli, A.; Sabatino, L.; Moncada, A.; Vetrano, F.; D’Anna, F. Nursery and Field Evaluation of Eggplant Grafted onto Unrooted Cuttings of Solanum torvum Sw. Sci. Hortic. 2014, 178, 203-210. [CrossRef]

11. Miceli, A.; Romano, C.; Moncada, A.; Piazza, G.; Torta, L.; D’Anna, F.; Vetrano, F. Yield and quality of mini-watermelon as affected by grafting and mycorrhizal inoculum. J. Agr. Sci. Tech. 2016, 18, 505-516.

12. Moncada, A.; Miceli, A.; Vetrano, F.; Mineo, V.; Planeta, D.; D’Anna, F. Effect of Grafting on Yield and Quality of Eggplant (Solanum melongena L.). Sci. Hortic. 2013, 149, 108-114. [CrossRef]

13. Rouphael, Y.; Schwarz, D.; Krumbein, A.; Colla, G. Impact of Grafting on Product Quality of Fruit Vegetables. Sci. Hortic. 2010, 127, 172-179. [CrossRef]

14. Basra, A. Plant Growth Regulators in Agriculture and Horticulture: Their Role and Commercial Uses; CRC Press Inc.: Boca Raton, FL, USA, 2000.

15. Hooley, R. Gibberellins: Perception, transduction and responses. Plant Mol. Biol. 1994, 26, $1529-1555$. [CrossRef] [PubMed]

16. Hedden, P.; Sponsel, V. A Century of Gibberellin Research. J. Plant Growth Regul. 2015, 34, 740-760. [CrossRef] [PubMed]

17. Sun, T.P. Gibberellin Signal Transduction in Stem Elongation \& Leaf Growth. In Plant Hormones; Davis, P.J., Ed.; Kluwer Academic Publishers: Dordrecht, The Netherlands, 2004; pp. 308-328.

18. Rodrigues, T.D.J.; Leite, I.C. Fisiologia vegetal-hormônios das plantas. Jaboticaba 2004, 19-37.

19. Azuma, T.; Ueno, S.; Uchida, N.; Yasuda, T. Gibberellin-induced elongation and osmoregulation in internodes of floating rice. Physiol. Plant. 1997, 99, 517-522. [CrossRef]

20. Bhaskar, S.; Vasantha Kumar, T.; Srivastava, H.C. Influence of growth regulators on production of herbage and oil in patchouli (Pogostemon patchouli). Ind. Perfum 1997, 41, 98-101.

21. Brock, T.G. Combined effects of hormones and light during growth promotion in primary leaves of Phaseolus vulgaris. Can. J. Bot. 1993, 71, 501-550. [CrossRef]

22. Emongor, V.E. Effect of benzyladenine and gibberellins on growth, yield and yield components of common bean (Phaseolus vulgaris). UNISWA Res. J. Agric. Sci. Technol. 2002, 6, 65-72. [CrossRef]

23. Gupta, V.N.; Datta, S.K. Influence of gibberellic acid on growth and flowering in chrysanthemum (Chrysanthemum morifolium Ramat) cv. Jayanti. Ind. J. Plant Physiol. 2001, 6, 420-422.

24. Khan, N.A.; Samiullah, M. Comparative effect of modes of gibberellic acid application on photosynthetic biomass distribution and productivity of rapeseed-mustard. Physiol. Mol. Biol. Plants 2003, 9, 141-145.

25. Richards, D.E.; King, K.E.; Ait-Ali, T.; Harberd, N.P. How gibberellin regulates plant growth and development: A molecular genetic analysis of gibberellin signaling. Annu. Rev. Plant Biol. 2001, 52, 67-88. [CrossRef] [PubMed]

26. Takei, K.; Takahashi, T.; Sugiyama, T.; Yamaya, T.; Sakakibara, H. Multiple routes communicating nitrogen availability from roots to shoots: A signal transduction pathway mediated by cytokinin. J. Exp. Bot. 2002, 53, 971-977. [CrossRef] [PubMed]

27. Wareing, P.F.; Phillips, I.D.J. Growth and Differentiation in Plants, 3rd ed.; Pergamon Press: Oxford, UK, 1981.

28. Yang, Y.Z.; Lin, D.C.; Guo, Z.Y. Promotion of fruit development in cucumber (Cucumis sativus) by thidiazuron. Sci. Hortic. 1992, 50, 47-51. [CrossRef]

29. Robert, E.C. Introduction: Nature, Occurrence and Functioning of Plant Hormones. In Biochemistry and Molecular Biology of Plant Hormones; Hooykaas, P.J.J., Hall, M.A., Libbenga, K.R., Eds.; Elsevier: Amsterdam, The Netherlands; New York, NY, USA; London, UK, 1999; pp. 3-22.

30. Shah, S.H.; Ahmad, I.; Samiullah, M. Effect of gibberellic acid spray on growth.; nutrient uptake and yield attributes during various growth stages of black cumin (Nigella sativa L.). Asian J. Plant Sci. 2006, 5, 881-884. 
31. Janick, J. Horticultural Science; Freeman \& Co.: San Francisco, CA, USA, 1979.

32. Khan, M.M.A.; Gautam, C.; Mohammad, F.; Siddiqui, M.H.; Naeem, M.; Khan, M.N. Effect of gibberellic acid spray on performance of tomato. Turk. J. Biol. 2006, 30, 11-16.

33. Khan, N.A.; Ansari, H.R. Samiullah Effect of gibberellic acid spray during ontogeny of mustard on growth, nutrient uptake and yield characteristics. J. Agron. Crop Sci. 1998, 181, 61-73. [CrossRef]

34. King, R.W.; Evans, L.T. Gibberellins and flowering of grasses and cereals: Prizing open the lid of the "florigen black box". Annu. Rev. Plant Biol. 2003, 54, 307-328. [CrossRef] [PubMed]

35. Mukherjee, R.K.; Prabhakar, B.S. Effect of gibberellin on rice yield response to nitrogen applied at heading and quality of seeds. Plant Soil 1980, 55, 153-156. [CrossRef]

36. Pal, P.; Yadav, K.; Kumar, K.; Singh, N. Effect of gibberellic acid and potassium foliar sprays on productivity and physiological and biochemical parameters of parthenocarpic cucumber cv. 'seven star F1'. J. Hortic. Res. 2016, 24, 93-100. [CrossRef]

37. Singh, S.P. Response of tomatoes to growth substances-A review. Adv. Hort. Forest. 1995, 4, $73-84$.

38. Shah, S.H. Effects of salt stress on mustard as affected by gibberellic acid application. Gen Appl. Plant Physiol. 2007, 33, 97-106.

39. Maggio, A.; Barbieri, G.; Raimondi, G.; De Pascale, S. Contrasting effects of $\mathrm{GA}_{3}$ treatments on tomato plants exposed to increasing salinity. J. Plant Growth Regul. 2010, 29, 63-72. [CrossRef]

40. Khan, N.A.; Mir, R.; Khan, M.; Javid, S. Effects of gibberellic acid spray on nitrogen yield efficiency of mustard grown with different nitrogen levels. Plant Growth Regul. 2002, 38, 243-247. [CrossRef]

41. Gelmesa, D.; Abebie, B.; Desalegn, L. Effects of Gibberellic acid and 2, 4-dichlorophenoxyacetic acid spray on fruit yield and quality of tomato (Lycopersicon esculentum Mill.). J. Plant Breed. Crop Sci. 2010, 2, 316-324.

42. Sonneveld, C.; Voogt, W. Plant Nutrition of Greenhouse Crops; Springer: New York, NY, USA, 2009.

43. Goto, E.; Both, A.J.; Albright, L.D.; Langhans, R.W.; Leed, A.R. Effect of dissolved oxygen concentration on lettuce growth in floating hydroponics. Acta Hortic. 1996, 440, 205-210. [CrossRef] [PubMed]

44. Fageria, N.K.; Baligar, V.C.; Li, Y.C. The role of nutrient efficient plants in improving crop yields in the twenty first century. J. Plant Nutr. 2008, 31, 1121-1157. [CrossRef]

45. McGuire, R.G. Reporting of objective color measurements. Hortic. Sci. 1992, 27, 1254-1255. [CrossRef]

46. Da Silva Vieira, M.R.; Citadini, V.; Lima, G.P.P.; de Souza, A.V.; de Souza Alves, L. Use of gibberellin in floriculture. Afr. J. Biotechnol. 2010, 9, 9118-9121.

47. Dayan, J.; Voronin, N.; Gong, F.; Sun, T.; Hedden, P.; Fromm, H.; Aloni, R. Leaf-induced gibberellin signaling is essential for internode elongation, cambial activity, and fiber differentiation in tobacco stems. Plant Cell 2012, 24, 66-79. [CrossRef]

48. Vivanco, J.M.; Flores, H.E. Control of Root Formation by Plant Growth Regulators. In Plant Growth Regulators in Agriculture and Horticulture: Their Role and Commercial Uses; Basra, A., Ed.; CRC Press Inc.: Boca Raton, FL, USA, 2000; pp. 1-26.

49. Buchanan, B.B.; Gruissem, W.; Jones, R.L. Biochemistry and Molecular Biology of Plants; American Society of Plant Physiologists: Rockville, MD, USA, 2000.

50. Arteca, R.N. Plant Growth Substances: Principles and Applications; Chapman and Hall Inc.: New York, NY, USA, 1996.

51. Liu, P.B.W.; Loy, B. Action of gibberellic acid on cell proliferation in the subapical shoot meristem of watermelon seedlings. Am. J. Bot. 1976, 63, 700-704. [CrossRef]

52. Moore, T.C. Biochemistry and Physiology of Plant Hormones; Springer-Verlag Inc.: New York, NY, USA, 1989.

53. Ogasawara, N.; Hiramasu, T.; Ishiyama, K.; Fushimi, H.; Suzuki, H.; Takagi, H. Effects of gibberellic acid and temperature on growth and root carbohydrates of Delphinium seedlings. Plant Growth Regul. 2001, 33, 181-187. [CrossRef]

54. King, R.W.; Moritz, T.; Evans, L.T.; Junttila, O.; Herlt, A.J. Long-day induction of flowering in Lolium temulentum involves sequential increases in specific gibberellins at the shoot apex. Plant Physiol. 2001, 127, 624-632. [CrossRef] [PubMed]

55. Eriksson, S.; Böhlenius, H.; Moritz, T.; Nilsson, O. GA 4 is the active gibberellin in the regulation of LEAFY transcription and Arabidopsis floral initiation. Plant Cell 2006, 18, 2172-2181. [CrossRef] [PubMed] 
56. Zhang, Y.; Zhang, S.; Lin, J.; Wang, Y.; Fang, X. Research progress on cloning and functional analysis of plant height genes in rice (Oryza sativa L.). Chin. Agr. Sci. Bull. 2014, 30, 78-89.

57. Achard, P.; Gusti, A.; Cheminant, S.; Alioua, M.; Dhondt, S.; Coppens, F.; Beemster, G.T.; Genschik, P. Gibberellin signaling controls cell proliferation rate in Arabidopsis. Curr. Biol. 2009, 19, 1188-1193. [CrossRef]

58. Ubeda-Tomás, S.; Federici, F.; Casimiro, I.; Beemster, G.T.; Bhalerao, R.; Swarup, R.; Doerner, P.; Haseloff, J.; Bennett, M.J. Gibberellin signaling in the endodermis controls Arabidopsis root meristem size. Curr. Biol. 2009, 19, 1194-1199. [CrossRef] [PubMed]

59. Broughton, W.J.; McComb, A.J. Changes in the pattern of enzyme development in gibberellin-treated pea internodes. Ann. Bot. 1971, 35, 213-228. [CrossRef]

60. Johri, M.M.; Varner, J.E. Enhancement of RNA synthesis in isolated pea nuclei by gibberellic acid. Proc. Natl. Acad. Sci. USA 1968, 59, 269-279. [CrossRef]

61. Mozer, T.J. Control of protein synthesis in barley aleurone layers by the plant hormones, gibberellic acid and abscisic acid. Cell 1980, 20, 479-485. [CrossRef]

62. Pain, S.K.; Dutta, J.K. Studies on growth and metabolism of Zea mays L. I. The effect of application of gibberellic acid on the growth and metabolism of seedlings. Indian Biol. 1977, 9, 38-43.

63. Roth Benjerano, N.; Lips, S.H. Hormonal regulation of nitrate reductase activity in leaves. New Phytol. 1970, 69, 165-169. [CrossRef]

64. Evins, W.H.; Varner, J.E. Hormonal control of polyribosome formation in barley aleurone layers. Plant Physiol. 1972, 49, 348-352. [CrossRef] [PubMed]

65. Broughton, W.J. Influence of gibberellic acid on nucleic acid synthesis in dwarf pea internodes. Biochem. Biophys. Acta 1968, 155, 308-310. [CrossRef]

66. Glasziou, K.T. Control of enzyme formation and inactivation in plants. Annu. Rev. Plant Physol. 1969, 20, 63-88. [CrossRef]

67. Seitz, K.; Lang, A. Invertase activity and cell growth in lentil epicotyls. Plant Physiol. 1968, 43, $1075-1082$. [CrossRef] [PubMed]

68. Crozier, A.; Turnbull, C.G.N. Gibberellins: Biochemistry and action in extension growth. What's New in Plant Physiol. 1984, 15, 9-12.

69. Wood, A.; Paleg, L.G. The influence of $\mathrm{GA}_{3}$ on the permeability of model membrane systems. Plant Physiol. 1972, 50, 103-108. [CrossRef]

70. Wood, A.; Paleg, L.G. Alteration of liposomal membrane fluidity by gibberellic acid. Aust. J. Plant Physiol. 1974, 1, 31-40. [CrossRef]

71. Al-Wakeel, S.A.M.; Hamed, A.A.; Dadoura, S.S. Interactive effects of water stress and gibberellic acid on mineral composition of fenugreek plant. Egypt. J. Physiol. Sci. 1995, 18, 269-282.

72. Ansari, H.R. Effect of Some Phytohormones and NPK on Growth and Metabolism of Mustard. Ph.D. Thesis, ; Aligarh Muslim University, Aligarh, India, 1996.

73. Aloni, B.; Daie, J.; Wyse, R.E. Enhancement of (14C)-sucrose export from source leaves of Vicia faba by gibberellic acid. Plant Physiol. 1986, 82, 962-966. [CrossRef] [PubMed]

74. Daie, J.; Watts, M.; Aloni, B.; Wyse, R.E. In vitro and in vivo modification of sugar transport and translocation in celery by phytohormones. Plant Sci. 1986, 46, 35-41. [CrossRef]

75. Estruch, J.J.; Pereto, J.G.; Vercher, Y.; Beltrán, J.P. Sucrose loading in isolated veins of Pisum sativum: Regulation by abscisic acid, gibberellic acid and cell turgor. Plant Physiol. 1989, 91, 259-265. [CrossRef] [PubMed]

76. Mulligan, D.R.; Patrick, J.W. Gibberellic-acid-promoted transport of assimilates in stems of Phaseolus vulgaris L.: Localised versus remote site (S) of action. Planta 1979, 145, 233-238. [CrossRef] [PubMed]

77. Hedden, P.; Thomas, S.G. Gibberellin biosynthesis and its regulation. Biochem. J. 2012, 444, 11-25. [CrossRef] [PubMed]

78. Sugiura, D.; Kojima, M.; Sakakibara, H. Phytohormonal Regulation of Biomass Allocation and Morphological and Physiological Traits of Leaves in Response to Environmental Changes in Polygonum cuspidatum. Front. Plant Sci. 2016, 7, 1189. [CrossRef] [PubMed] 
79. Sugiura, D.; Sawakami, K.; Kojima, M.; Sakakibara, H.; Terashima, I.; Tateno, M. Roles of gibberellins and cytokinins in regulation of morphological and physiological traits in Polygonum cuspidatum responding to light and nitrogen availabilities. Funct. Plant Bio. 2015, 42, 397-409. [CrossRef]

80. Bultynck, L.; Lambers, H. Effects of applied gibberellic acid and paclobutrazol on leaf expansion and biomass allocation in two Aegilops species with contrasting leaf elongation rates. Physiol. Plant. 2004, 122, 143-151. [CrossRef]

81. Tang, X.M.; Liu, C.; Zhong, R.C.; Jiang, J.; Han, Z.Q.; He, L.Q.; Li, Z.; Xiong, F.Q.; Tang, R.H. Comparative studies on the chemical regulation of peanuts by paclobutrazol, mepiquat chloride and chlorocholine chloride. J. South. Agric. 2011, 42, 603-605.

82. Xie, B.T.; Wang, Q.M.; Zhang, H.Y.; Li, A.X.; Hou, F.Y.; Wang, B.Q.; Dong, S.X.; Zhang, L.M. The effect of plant growth regulators on the yield and phytohormone concentration in sweet potato. Acta Agric. Boreali-Sin. 2016, 31, 155-161.

83. Zhang, Y. Research status of plant growth regulators on crop regulation. Mod. Agric. 2016, 5, 31-34.

84. Han, H.Y.; Wang, F.A.; Chen, B.; Li, B.A.; Zhang, W.F.; Tian, X.L.; Li, Z. Effect of nitrogen fertilizer on plant growth and yield formation of cotton applied with fortified DPC. J. Chin. Agric. Univ. 2017, 22, 12-20.

85. Zhang, M.; Liu, M.; Zhang, Y.; Ji, Y.; Zhao, M.; Wu, Z. Effect of different plant growth regulator added in nutrient solution on growth and development of summer tomato seedling. North Hortic. 2017, 6, 8-13.

86. Khan, N.A. Effect of gibberellic acid on carbonic anhydrase, photosynthesis, growth and yield of mustard. Biol. Plant. 1996, 38, 145. [CrossRef]

87. Sultemeyer, D.; Schmidt, C.; Fock, H.P. Carbonic anhydrases in higher plants and aquatic microorganisms. Physiol. Plant. 1993, 88, 179-190. [CrossRef]

88. Kachru, R.B.; Anderson, L.E. Chloroplast and cytoplasmic enzymes. Planta 1974, 118, 235-240. [CrossRef]

89. Khan, N.A. Variation in carbonic anhydrase activity and its relationship with photosynthesis and dry mass of mustard. Photosynthetica 1994, 30, 317-320.

90. Yuan, L.; Xu, D.Q. Stimulation effect of gibberellic acid short-term treatment on leaf photosynthesis related to the increase in Rubisco content in broad bean and soybean. Photosynth. Res. 2001, 68, 39-47. [CrossRef]

91. Ihl, M.; Shene, C.; Scheuermann, E.; Bifani, V. Correlation for pigment content through color determination using tristimulus values in a green leafy vegetable, Swiss chard. J. Sci. Food Agric. 1994, 66, 527-531. [CrossRef]

92. Madeira, A.C.; Ferreira, A.; de Varennes, A.; Vieira, M.I. SPAD meter versus tristimulus colorimeter to estimate chlorophyll content and leaf color in sweet pepper. Commun. Soil Sci. Plant Anal. 2003, 34, 2461-2470. [CrossRef]

93. Magdah, G.M. Impact of biostimulant and synthetic hormone gibberellic acid on molecular structure of Solanum melongena L. J. Mol. Biol. Res. 2016, 6, 100-110. [CrossRef]

94. Mbandlwa, N.P.; Fotouo, M.H.; Maboko, M.M.; Sivakumar, D. Stomatal conductance, leaf chlorophyll content, growth, and yield of sweet pepper in response to plant growth regulators. Int. J. Veg. Sci. 2019, 1-11. [CrossRef]

95. Wheeler, A.W.; Humphies, E.C. Effect of gibberellic acid on growth, gibberellin content, and chlorophyll content of leaves of potato (Solanum tuberosum). J. Exp. Bot. 1963, 14, 132-136. [CrossRef]

96. Mahindre, P.B.; Jawarkar, A.K.; Ghawade, S.M.; Tayade, V.D. Effect of different concentration of plant growth regulators on growth and quality of green chilli. J. Pharm. Phytochem. 2018, 1, 3040-3042.

97. Göring, H.; Koshuchowa, S.; Deckert, C. Influence of gibberellic acid on stomatal movement. Bioche. Physiol. Pflanz. 1990, 186, 367-374. [CrossRef]

98. Chanda, S.V.; Sood, C.R.; Reddy, V.S.; Singh, Y.D. Influence of plant growth regulators on some enzymes of nitrogen assimilation in mustard seedlings. J. Plant Nutr. 1998, 21, 1765-1777. [CrossRef]

99. Lee, S.K.; Kader, A.A. Preharvest and postharvest factors influencing vitamin C content of horticultural crops. Postharvest Biol. Technol. 2000, 20, 207-220. [CrossRef]

100. Stefanelli, D.; Goodwin, I.; Jones, R. Minimal nitrogen and water use in horticulture, effects on quality and content of selected nutrients. Food Res. Int. 2010, 43, 1833-1843. [CrossRef] 
101. Miceli, A.; Miceli, C. Effect of Nitrogen Fertilization on the Quality of S wiss Chard at Harvest and during Storage as Minimally Processed Produce. J. Food Qual. 2014, 37, 125-134. [CrossRef]

102. Mozafar, A. Plant Vitamins. Agronomic, Physiological and Nutritional Aspects; CRC Press Inc.: Boca Raton, FL, USA, 1994.

(C) 2019 by the authors. Licensee MDPI, Basel, Switzerland. This article is an open access article distributed under the terms and conditions of the Creative Commons Attribution (CC BY) license (http://creativecommons.org/licenses/by/4.0/). 